University of Nebraska - Lincoln

DigitalCommons@University of Nebraska - Lincoln

\title{
The Russell Gold Deposit, Carolina Slate Belt, North Carolina
}

Terry Klein

U.S. Geological Survey, Denver Federal Center, Box 25046, MS 905, Denver, Colorado 80225

Charles Cunningham

U.S. Geological Survey, MS 954, National Center, Reston, Virginia 20192

M.A.V. Logan

National Museum of Natural History, Smithsonian Institution

Robert R. Seal II

U.S. Geological Survey, 954 National Center, Reston, Virginia 20192, USA, rseal@usgs.gov

Follow this and additional works at: https://digitalcommons.unl.edu/usgsstaffpub

Part of the Earth Sciences Commons

Klein, Terry; Cunningham, Charles; Logan, M.A.V.; and Seal II, Robert R., "The Russell Gold Deposit, Carolina Slate Belt, North Carolina" (2007). USGS Staff -- Published Research. 346.

https://digitalcommons.unl.edu/usgsstaffpub/346

This Article is brought to you for free and open access by the US Geological Survey at DigitalCommons@University of Nebraska - Lincoln. It has been accepted for inclusion in USGS Staff -- Published Research by an authorized administrator of DigitalCommons@University of Nebraska - Lincoln. 


\title{
The Russell Gold Deposit, Carolina Slate Belt, North Carolina
}

\author{
Terry L. KLein, ${ }^{\dagger}$ \\ U.S. Geological Survey, Denver Federal Center, Box 25046, MS 905, Denver, Colorado 80225
}

Charles G. Cunningham, U.S. Geological Survey, MS 954, National Center, Reston, Virginia 20192

\author{
M.A.V. LOGAN, \\ Department of Mineral Sciences, NHB 119, National Museum of Natural History, Smithsonian Institution, Washington, DC 20560
}

AND Robert R. SEAL II

U.S. Geological Survey, MS 954, National Center, Reston, Virginia 20192

\begin{abstract}
Gold deposits have been mined in the Carolina slate belt from the early 1800s to recent times, with most of the production from large mines in South Carolina. The Russell mine, one of the larger producers in North Carolina, is located in the central Uwharrie Mountains, and produced over $470 \mathrm{~kg}$ of gold. Ore grades averaged about 3.4 grams per tonne (g/t), with higher-grade zones reported. The Russell deposit is interpreted to be a sediment-hosted, gold-rich, base-metal poor, volcanogenic massive sulfide deposit in which gold was remobilized, in part, during Ordovician metamorphism. The ore was deposited syngenetically with laminated siltstones of the late Proterozoic Tillery Formation that have been metamorphosed to a lower greenschist facies. The Tillery Formation regionally overlies subaerial to shallow marine rhyolitic volcanic and volcaniclastic rocks of the Uwharrie Formation and underlies the marine volcanic and sedimentary rocks of the Cid Formation. Recent mapping has shown that a rhyolitic dome near the Russell mine was extruded during the deposition of the lower part of the Tillery Formation, at about the same time as ore deposition. Relict mafic rock fragments present in the ore zones suggest contemporaneous bimodal (rhyolite-basalt) volcanism. The maximum formation age of the Russell deposit is younger than $558 \mathrm{Ma}$, which is similar to that of the larger, well known Brewer, Haile, and Ridgeway deposits of South Carolina.

Gold was mined from at least six zones that are parallel to the regional metamorphic foliation. These strongly deformed zones consist of northeast-trending folds, high-angle reverse faults, and asymmetric doubly plunging folds overturned to the southeast. The dominant structure at the mine is an asymmetric doubly plunging anticline with the axis trending $\mathrm{N} 45^{\circ} \mathrm{E}$, probably related to late Ordovician (456 $\pm 2 \mathrm{Ma}$ ) regional metamorphism and deformation.

Two stages of pyrite growth are recognized. Stage 1, primary, spongy pyrite, is present in thin massive sulfide layers parallel to bedding and intergrown with pyrrhotite, chalcopyrite, sphalerite, and sparse arsenopyrite. Stage 2, secondary pyrite, is present as euhedral, idiomorphic rims on spongy pyrite and as veinlets that parallel the regional foliation. Stage 1 pyrite was deposited syngenetically or diagenetically during or soon after sedimentation. Stage 2 pyrite overgrowths and veins resulted from recrystallization or remobilization of stage 1 pyrite, probably during deformation related to Ordovician regional metamorphism. It is proposed that the spongy texture of the stage 1 pyrite represents nucleation and growth of pyrite on organic matter, possibly of bacterial origin. Other textures, such as geometric voids in spongy pyrite, As-rich zones surrounding central voids, $60-\mu \mathrm{m}$ ring structures composed of spongy pyrite, and layers of spongy pyrite interlayered with bedding laminations, also appear to indicate replacement of organic matter by pyrite. Stage 1 pyrite contains up to 0.06 wt percent gold. The $\delta^{34} \mathrm{~S}$ values of pyrite in and near pyritic ore (3.5-4.5\%o), in the rhyolite dome (5.1-5.4\%o) and in the Tillery Formation (5.9-6.2\%o) are interpreted to reflect mixing of sulfur derived from igneous and seawater sources. Whole-rock $\delta^{18} \mathrm{O}$ values of nearby unaltered mudstone are about 11 per mil whereas those from altered mudstone at the deposit are 7.4 to 10.6 per mil. The lower $\delta^{18} \mathrm{O}$ values are interpreted to indicate possible high-temperature exchange between relatively low $\delta^{18} \mathrm{O}$ hydrothermal fluids and the wall rocks. Gold, As, K, and Mo are enriched relative to the regional background in both the ore zones and in pyrite veins and disseminations in the nearby rhyolite dome, suggesting a possible genetic link between the rhyolitic volcanism and the gold mineralization.
\end{abstract}

\section{Introduction}

The Carolina slate belt was the site of the first lode gold mine in the United States, in 1829, and has been an intermittent source of precious metals since that time. Mining activity

\footnotetext{
† Corresponding author: e-mail: tklein@usgs.gov
}

was brisk until about 1849, when the California gold fields in the West began attracting miners. Renewed interest in the Carolina slate belt in the 1980s led to the discovery of new deposits and resources. Two deposits, the Haile and Ridgeway deposits of northern South Carolina, with total resources of 48 and 52 tonnes (t) $\mathrm{Au}$, respectively, have recently been 
mined. As of 1995, estimates from more than 20 lode deposits, with a minimum of $20,000 \mathrm{t}$ of ore in each deposit, indicate a total of $33.5 \mathrm{Mt}$ of mined ore containing $38 \mathrm{t}$ of silver and $65 \mathrm{t}$ of gold (Mineral Resources Data System, U.S. Geological Survey). Unmined resources at that time included 41.5 Mt of ore containing $18 \mathrm{t}$ of silver and $62 \mathrm{t}$ of gold.

The Russell mine, in the central part of the Carolina slate belt (Fig. 1), has been an historically important gold producer in North Carolina. It is similar in host lithology, alteration style, and geochemistry to the larger Haile and Ridgeway deposits. The deposit is hosted in relatively low grade greenschist facies rocks, and it is relatively well exposed and accessible. A limited amount of core from recent exploration drilling also was available for study. Gold production from the Russell mine began in 1882 and totaled about $470 \mathrm{~kg}$ (Nitze and Hanna, 1896; Pardee and Park, 1948). Grades averaged about $3.4 \mathrm{~g} / \mathrm{t}$ with local high-grade zones reported (Pardee and Park, 1948; Kinkel, 1974). The mine, located in the Uhwarrie Mountains about $22 \mathrm{~km}$ northeast of Albemarle, North Carolina (Figs. 1 and 2a, b), consists of four open pits. The Coggins property, located about $1 \mathrm{~km}$ to the south (Fig. 2a), contains a deposit similar to the Russell but was not investigated. An evaluation in 1990 of the Russell and Coggins properties identified reserves of 3,600,000 $t$ with an average grade of $1.75 \mathrm{~g} / \mathrm{t}$ gold (Skillings Mining Review, 1993).

Here, we describe the geology, sulfide mineralogy, wall-rock alteration, and geochemistry of a diamond drill core from the Russell deposit, including a nearby rhyolite dome, and compare the Russell deposit with others in the Carolina slate belt. The study has regional significance because the Russell deposit has many features in common with the Haile deposit, which has been variously interpreted to be syntectonic - and related to shear zones (Tomkinson, 1988) or fold development (Hayward, 1992)—or syngenetic (Foley et al., 2001).

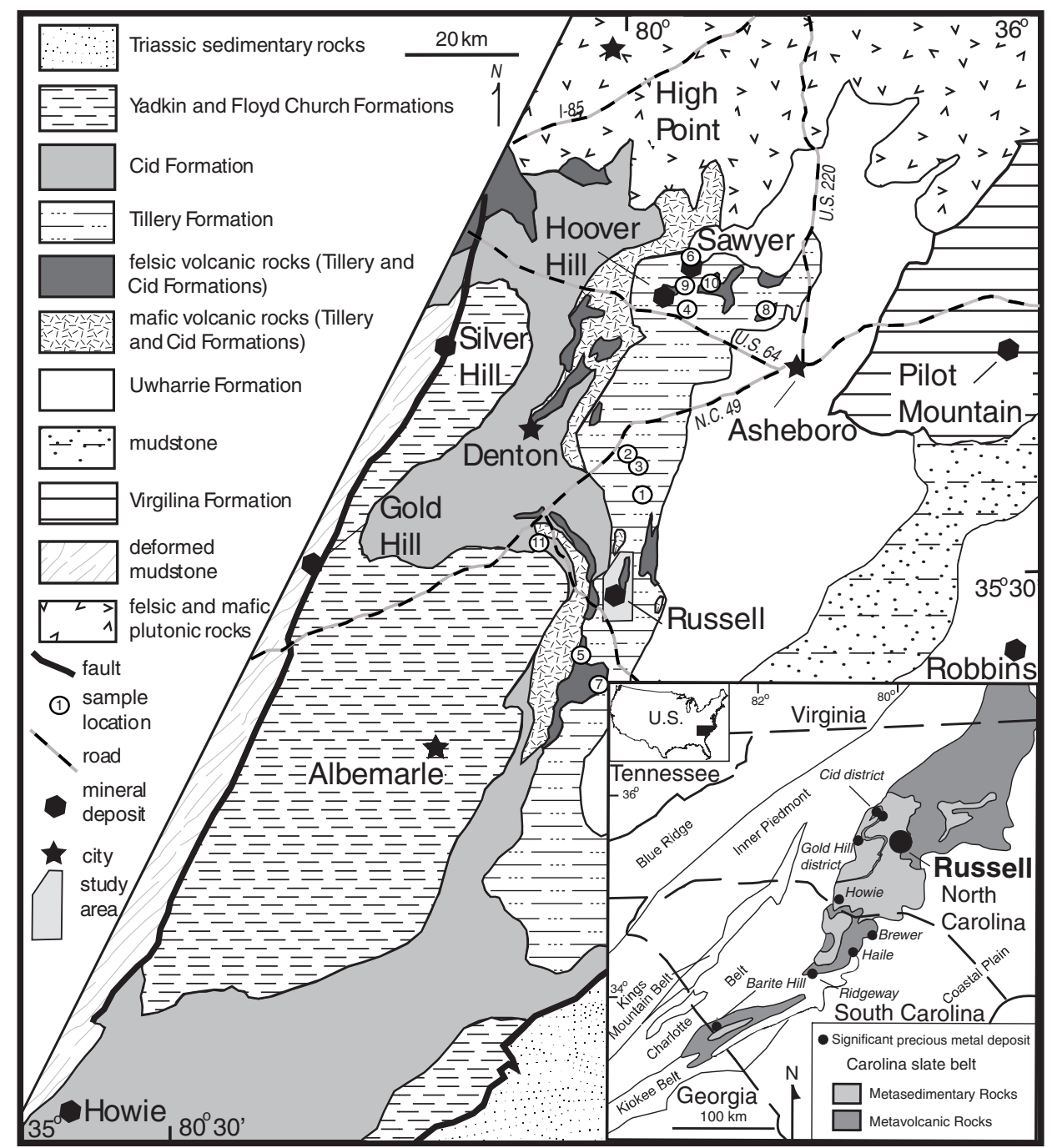

FIG. 1. The Russell mine, in the north-central part of the Carolina slate belt, is one of several gold deposits located within about $1 \mathrm{~km}$ of the regional contact between metasedimentary and metavolcanic rocks (inset). The mine is located within the sedimentary-rock dominated Tillery Formation overlying the felsic volcanic rocks of the Uwharrie Formation and underlying the mixed sedimentary and volcanic Cid Formation. Locations of regional geochemical and stable isotope samples referred to in the text and tables are indicated. Analyses of samples 1 through 10 are in Table 2 and sample 11 is in Table 3. Geology is modified after Conley (1962a), Goldsmith et al. (1988), and Seiders (1981). 


\section{Geologic Setting}

Regional geology

The Tillery Formation, which hosts the Russell deposit, consists mostly of thinly laminated siltstones and mudstones metamorphosed to greenschist facies (Conley, 1962a; Stromquist et al., 1971; Stromquist and Henderson, 1985) (Fig. 3). Metamorphic fabrics are typically poorly developed; areas with well-developed foliation are restricted to northeast-trending shear zones (Offield et al., 1995). Throughout the region, the Tillery Formation has extensive exposures of rhyolite and limited exposures of vesicular basalt and basaltic andesite with associated hyaloclastic tuff and breccia (Stromquist and Henderson, 1985). The Tillery Formation regionally overlies the dominantly rhyolitic volcanic and volcaniclastic rocks of the Uwharrie Formation. Rhyolites in the Tillery and underlying Uwharrie Formation are subalkaline with total alkali content of 5 to 8.5 wt percent and silica content between 72 and 77 wt percent (R.P. Koeppen, U.S. Geological Survey, unpub. data; Feiss, 1982).

Regionally, there is a strong spatial association between large gold deposits such as the Haile, Brewer, and Ridgeway gold deposits of South Carolina, and the contact between similar underlying felsic volcanic units and overlying laminated sedimentary rock units (Fig. 1) (Worthington and Kiff, 1970; Feiss and Wesolowski, 1986, 1990; Feiss et al., 1993). Worthington and Kiff (1970) and Feiss (1988) have suggested that the sedimentary-volcanic contact perhaps represents a fault-bounded depositional basin along which gold deposits were localized.

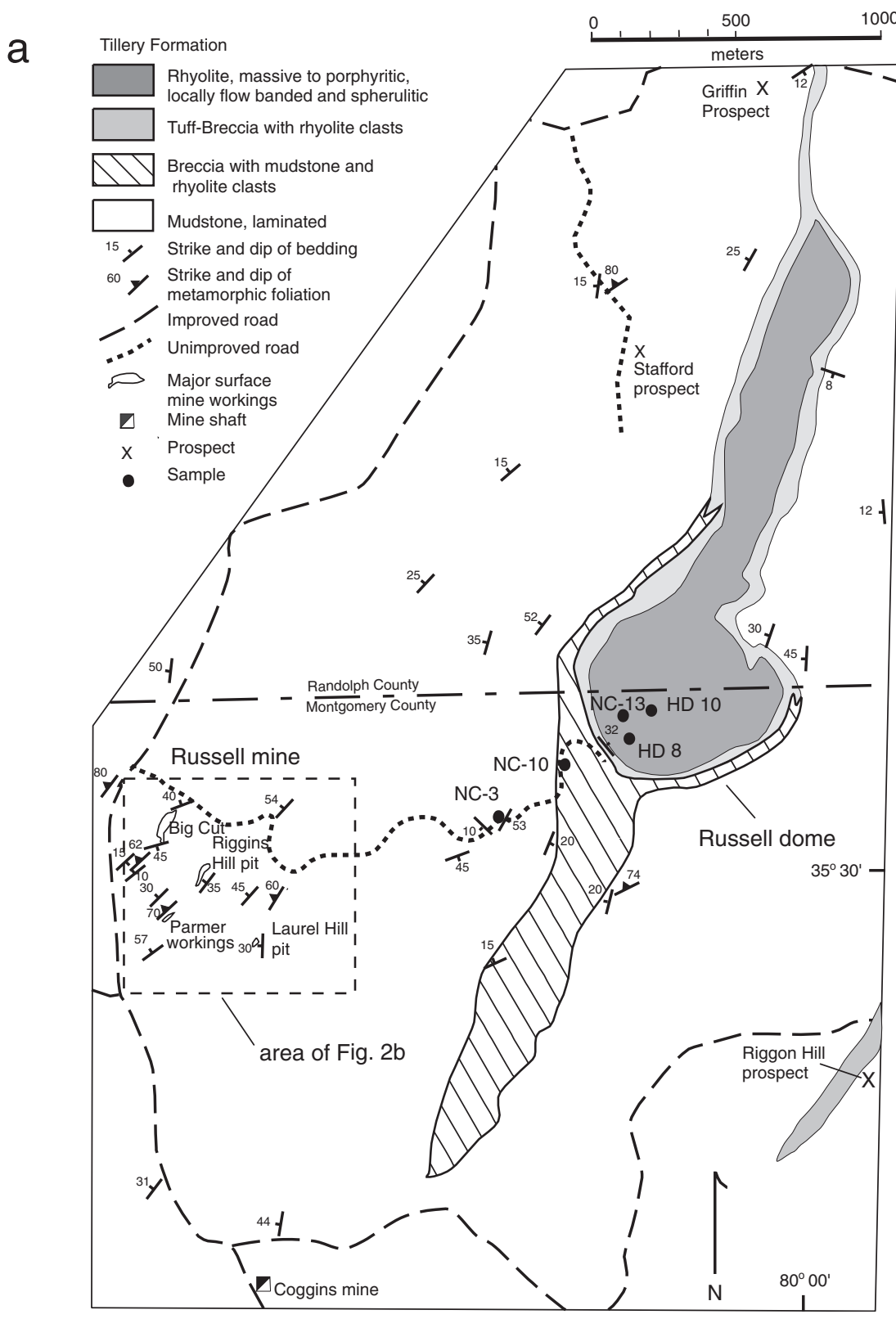

Fig. 2. a. Geologic setting of the Russell mine and dome. b. Northeast trend of the gold "leads" from Kerr and Hanna (1888) and location of drill hole CYR 5. Structural data is from T.W. Offield and T.L. Klein (unpub. data). 


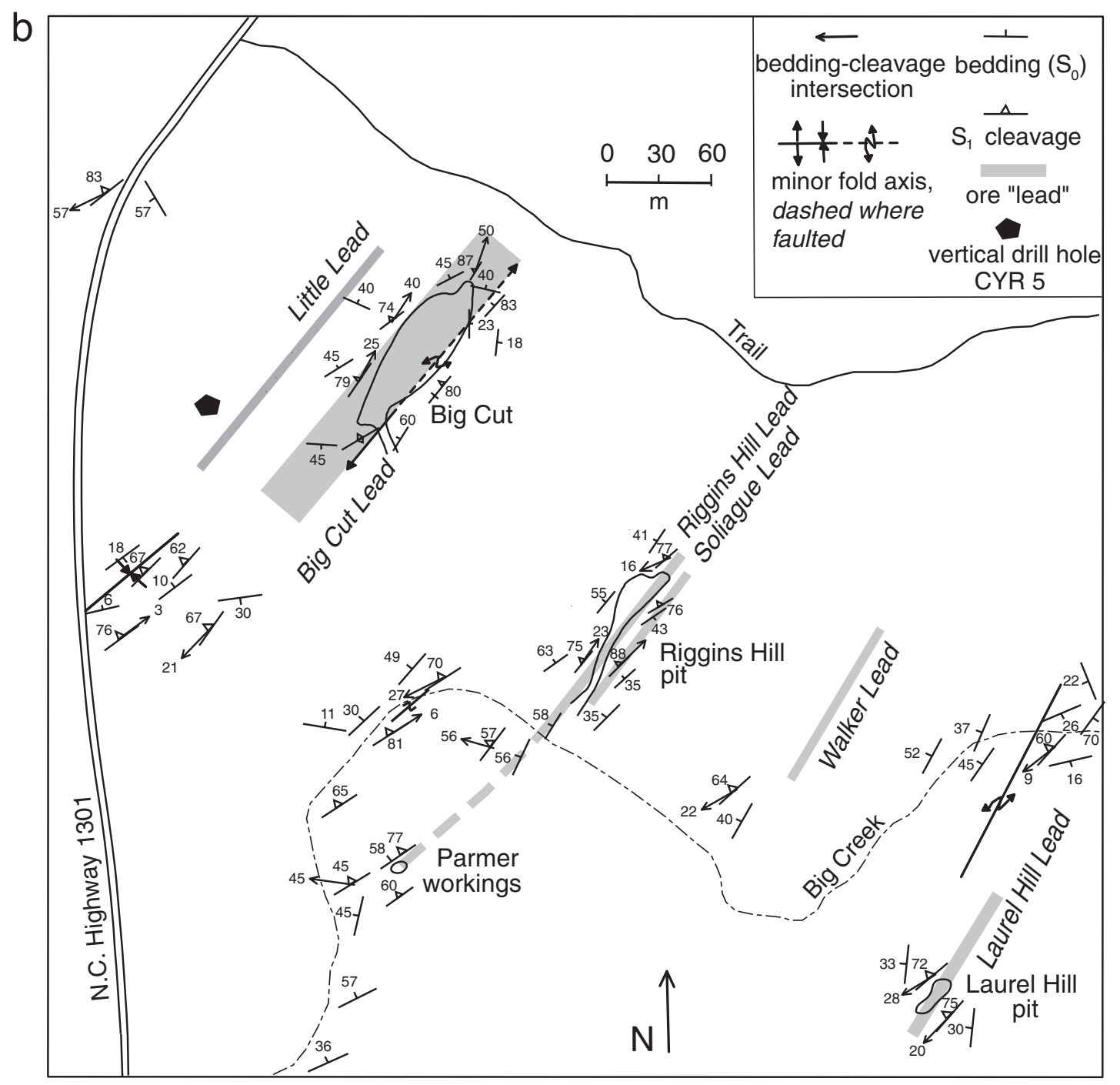

FIG. 2. (Cont.)

Mafic rocks in the Tillery Formation are mainly tholeiitic and include basaltic flows, tuffs, dikes, and sills. The volcanic activity in this area was most likely related to subduction in either a mature island arc or continental margin arc environment (Feiss, 1982; Rogers, 1982). Feiss et al. (1993) proposed that the development of a thick sedimentary sequence overlying the thick subaerial volcanic sequence of the Uwharrie Formation was the result of rifting of an existing magmatic arc. Kozuch (1994), based on geochemical data, suggested that rhyolites in the Tillery Formation formed in a back-arc extensional setting in a mature volcanic arc. A broad range of Sm-Nd values (Wortman et al., 2000) and the presence of older zircons in samples from all of the volcanic units in this part of the Carolina slate belt imply that the volcanic arcs were developed on mature continental crust (Ingle, 1999).

Metal deposits in volcanic-sedimentary rocks of the central and eastern Piedmont

The Carolina slate belt contains the most significant gold deposits in the eastern United States. In the first comprehensive study of these deposits, Pardee and Park (1948) classified all of the deposits as mesothermal or hypothermal veins (Lindgren, 1933). Many recent studies of base and precious metal deposits in the Carolina slate belt have favored a volcanogenic origin, recognizing their strata-bound nature, and conclude that they were formed in an epithermal environment related to subaerial or subaqueous hot springs (Worthington and Kiff, 1970; Spence et al., 1980; Worthington et al., 1980; Bell, 1982; Feiss, 1982; Klein et al., 1998; Clark et al., 1999; Foley et al., 2001). At the Haile gold mine, Tomkinson (1988) concluded that the mineralization was not syngenetic but was related to shearing and production of phyllonitic zones. Hayward (1992) concluded that mineralization at the Haile mine was syntectonic and localized by doubly plunging anticlinal folds. Our studies suggest a more complex history in which syngenetic gold-bearing sulfide minerals were deposited on the sea floor during the latest Precambrian, followed by overprinting by syntectonic hydrothermal alteration in the Ordovician that remobilized portions of the early syngenetic mineralization into highly deformed ore zones in attenuated east-verging asymmetric folds. 

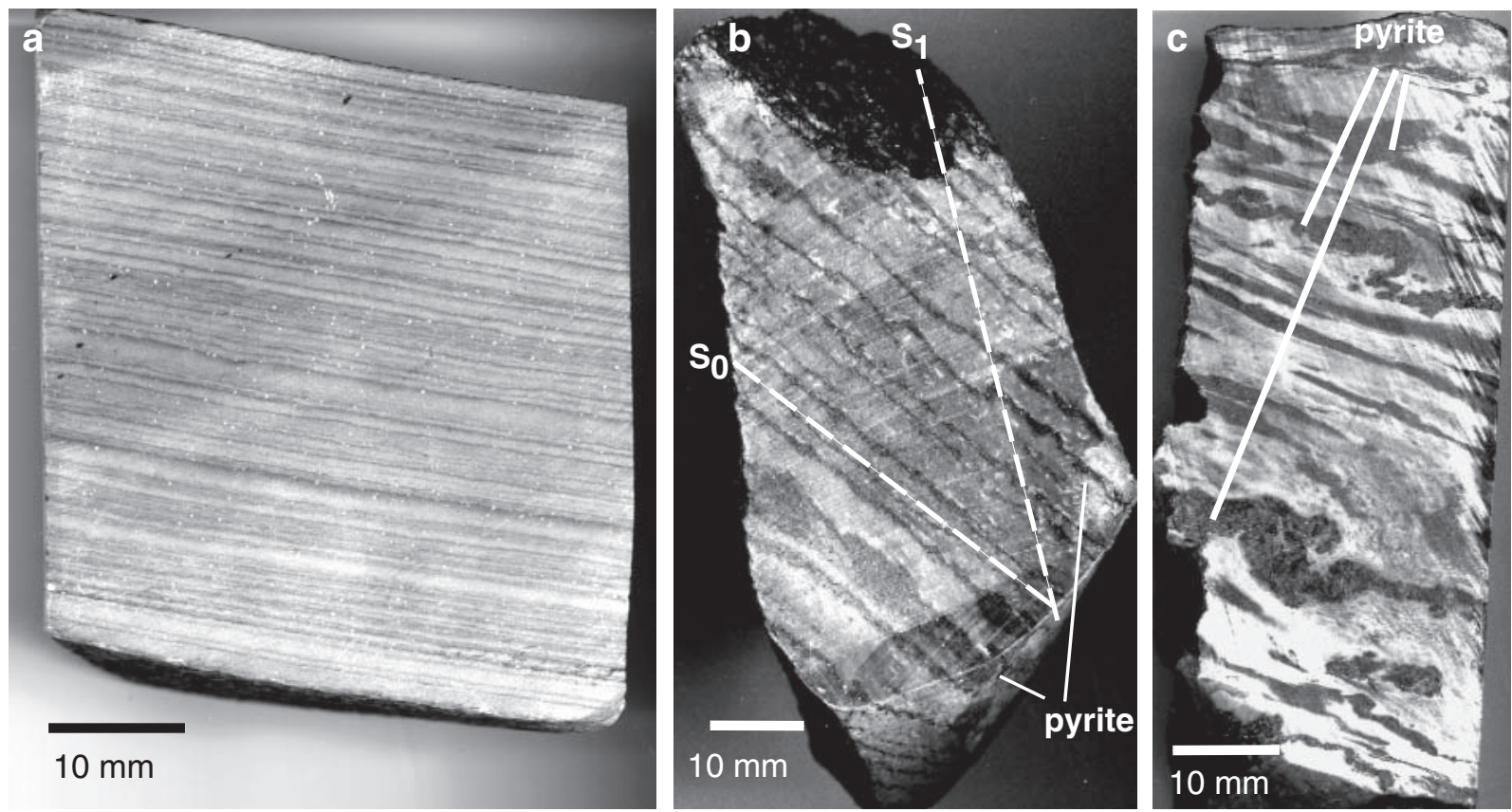

FIG. 3. Rock textures from the Russell mine. a. Undeformed laminated mudstone typical of Tillery Formation (note lack of fabric other than bedding, $\mathrm{S}_{0}$ ). Drill hole CYR 5, $24 \mathrm{~m}$. b. Pyrite beds (dark) interlaminated with siltstone (light). Low amplitude folds are caused by warping of $S_{0}$ by $S_{1}$. Drill hole CYR5, $39 \mathrm{~m}$. c. Interlayered pyrite (dark) and sediment beds $\left(S_{0}\right)$ intensely folded by $S_{1}$. Pyrite (stage 1 ) is commonly recrystallized to coarser grained pyrite (Stage 2 ) but retains the $S_{0}$ orientation with development of minor discordant veinlets (not shown) that generally follow $\mathrm{S}_{1}$. Drill hole CYR5 at $87 \mathrm{~m}$.

Several small, Zn-rich volcanogenic massive sulfide (VMS) deposits (i.e., Cid, Gold Hill, North Carolina; Barite Hill, South Carolina; Fig. 1) are found in finely laminated metasediments of similar age to the host rocks of the Russell deposit and are associated with submarine rhyolitic volcanic centers (Laney, 1910; Pogue, 1910; Guthrie, 1980; Indorf, 1981; Carpenter et al., 1982; Unger, 1982; Clark et al., 1999). These deposits typically contain pyrite, base-metal sulfides, and pyrrhotite; a few contain significant barite. Zoned footwall chloritic and sericitic alteration is common, as are exhalative chert horizons. $\delta^{34} \mathrm{~S}$ values are generally high (>12.5\%o) (LeHuray, 1984; Seal et al., 1997, 2001). These deposits have many characteristics of kuroko-type submarine exhalative systems (Franklin et al., 1981).

Other hydrothermal deposits in the region (Brewer, South Carolina; Pilot Mountain and Robbins, North Carolina) contain aluminous alteration assemblages (pyrophyllite, andalusite, and topaz), and have been classified as porphyry-related and (or) high-sulfidation subaerial epithermal deposits (Schmidt, 1985; Klein and Criss, 1988; Scheetz, 1991).

Other gold deposits, including many that lie along the Gold Hill fault zone (Fig. 1), bordering the west edge of the Carolina slate belt, such as the Howie and Gold Hill deposits in North Carolina, are mesothermal, epigenetic, low-sulfide gold quartz veins. These deposits were emplaced along regional shear zones and are related to regional metamorphism and folding (Schroeder, 1987; Tomkinson, 1988; Hayward, 1992).

\section{Local geology}

The finely laminated mudstones of the Tillery Formation (Fig. 3a) strike about $\mathrm{N} 45^{\circ} \mathrm{E}$ with a moderate dip to the northwest, which is essentially parallel to the contact with the Uwharrie Formation to the east (Stromquist and Henderson, 1985). For the most part, the Tillery mudstones are in their original, stratigraphically upright position. Near the Russell mine, the Tillery Formation is locally strongly deformed by northeast-trending folds, high-angle reverse faults, and attenuated, asymmetric folds slightly overturned to the southeast. Between the zones of strong deformation, the rocks face upward and are nearly flat lying or dip moderately to the west. The foliation trends $\mathrm{N} 45^{\circ} \mathrm{E}$ and has a steep westerly dip (Fig. 2a).

The Russell dome is a rhyolitic volcanic dome about $0.6 \times$ $2 \mathrm{~km}$ in size, $1.1 \mathrm{~km}$ northeast of the Russell mine (Fig. 2a). It is similar to several vitrophyric rhyolite domes in the upper part of the Uwharrie Formation-for example, at the Sam Christian gold mine, $24 \mathrm{~km}$ to the southeast (Pardee and Park, 1948; Nelson and Feiss, 1990). Similar but larger rhyolitic centers in the basal Tillery Formation occur at Caraway Mountain near Asheboro, North Carolina, $30 \mathrm{~km}$ northeast, and near Badin Lake, $10 \mathrm{~km}$ to the south (Koeppen and Klein, 1989).

The rhyolite is porphyritic with sparse feldspar, biotite, and primary almandine phenocrysts in an aphanitic groundmass. Much of the dome is massive to finely flow banded, with layers about $1 \mathrm{~mm}$ thick. Rhyolite near the base of the hill is flow banded and locally spherulitic, whereas on the upper part of the hill it is generally plagioclase-phyric and massive. A 3- to 4-m-thick layer of tuff, possibly a tuff ring, now mostly weathered to clay, dips inward under the dome. Near the southwest edge of the dome the tuff unit strikes $\mathrm{N} 45^{\circ} \mathrm{W}$ and dips $32^{\circ}$ northeast beneath the dome and appears to have been deformed as the rhyolite was extruded. The dome flares upward 
and outward over the sediments, affirming that the dome is right side up.

The rhyolite is cut by two generations of quartz veinlets. The earliest generation trends $\mathrm{N} 50^{\circ} \mathrm{E}$ and dips $65^{\circ}$ to $70^{\circ}$ $\mathrm{SE}$, consists of light gray vitreous quartz and contains up to 1 percent pyrite, with a vein thickness of 1.5 to $4.0 \mathrm{~cm}$. The later veins crosscut the northeast-trending set, with an orientation of $\mathrm{N} 05^{\circ} \mathrm{E}$ and dip $80^{\circ} \mathrm{E}$. They are generally thinner $(0.5-1.5 \mathrm{~cm})$ and contain less pyrite. Both sets of veinlets are most common in rhyolite that exhibits flow banding and spherulites.

A prominent low ridge extends southwest from the dome within the Tillery Formation where the relationship between the Tillery Formation sedimentation and the extrusion of the dome can be seen in outcrop (Fig. 2a). Here, the siltstones contain abundant disseminated pyrite. The character of the rock changes upward where clasts and blocks of laminated siltstones, up to $1 \mathrm{~m}$ in diameter, are incorporated in the siltstone. In the upper part of this sedimentary breccia, fragments of spherulitic rhyolite are common within the laminated mudstone matrix and indicate the dome was extruded during deposition of the Tillery Formation.

Several thin basaltic hyaloclastitic breccia units were observed in mudstones near the dome. Fine-grained basaltic breccias with a fine-grained sedimentary matrix also occur in rocks at the Russell deposit.

\section{Deposit geology}

Previous investigations of the Russell deposit include short descriptions of the mine (Kerr and Hanna, 1888; Nitze and Hanna, 1896; Nitze and Wilkens, 1897), an excellent summary of the geology of the deposit by Pardee and Park (1948), and the results of geochemical sampling (Kinkel, 1974). Exposures near the deposit are restricted to areas within the open pit and at a few sites along the major drainages. The remainder of the area is typically covered with thick soil and saprolite and variably thick vegetation.

The deposit consists of multiple northeast-trending mineralized zones that have been exploited from several open cuts and limited underground development. Six ore zones were described by Nitze and Wilkens (1897) and are shown in relation to the local structure in Figure 2b. The thicknesses of northeast-trending, gold-bearing zones are shown approximately to scale and range from 3 to $15 \mathrm{~m}$. They consist chiefly of pyrite and fine-grained quartz alteration which grade outward into unmineralized rock. Mine development followed ore zones that roughly parallel the regional foliation $\left(S_{1}\right)$ and that are located at structural discontinuities, as defined by dip reversals or marked perturbations of bedding $\left(\mathrm{S}_{0}\right)$. In general, each zone consists of a silica-rich, gold-bearing rock hosted by thinly bedded, sericite- and chlorite-altered siltstones and mudstones. Locally, intense carbonate replacement is observed in the drill core and is associated with peripheral sericite-chlorite alteration and with late, discordant quartz and calcite veinlets.

In core, the mineralization mainly consists of bedding-parallel layers of fine-grained pyrite that are locally associated with silicified and structurally disrupted zones. These pyrite layers are locally deformed by $\left(\mathrm{S}_{1}\right)$, as lenses and pods, or attenuated disharmonic folds (Fig. 3b, c). Some layers of mas- sive pyrite, ranging in thickness from several centimeters to about $1 \mathrm{~m}$, do not have recognizable alteration envelopes but occur in rocks that have experienced widespread sericitic alteration with no apparent silicification or quartz veining.

The dominant structure at the Big Cut, the largest of the surface workings, is an asymmetric, doubly plunging anticline with the axis trending $\mathrm{N} 45^{\circ} \mathrm{E}$ (Fig. 2b). The open pit follows a silicified gold-bearing zone along the axis of the anticline, parallel to the foliation. The southeastern limb of the anticline dips $80^{\circ} \mathrm{SE}$, whereas the northwestern limb dips $50^{\circ}$ NW. The east side of the deposit terminates against a highangle reverse fault that cuts off the alteration and sulfide mineralization. The crosscutting relationships observed here suggest that this fault caused the attenuation of the bottom limb of the asymmetric fold after hydrothermal alteration and gold deposition. The deformation extends to the north of the Big Cut, but silicification and precious metals are absent in this area, as determined from several drill holes. Drilling south of the Big Cut indicates that the ore zone plunges to the southwest. Observations in the Riggins Hill and Soliague workings also suggest that sulfide mineralization exposed along the axes of east-verging folds that are related to southeast-directed compression. In the Riggins Hill cut, two high-angle reverse faults cut the anticline, but only minor displacement of bedding is observed (Fig. 2b).

Geologic relationships in the Big Cut exposures are complicated by postore faulting. However, the Little Lead ore zone, which is exposed only in drill core, lies immediately to the west (Fig. 2b), is structurally less complex, and was chosen for detailed study from among the 12 drill holes that were examined during this study. A 134-m-deep drill hole, CYR 5, was examined and sampled to establish the character of the alteration and mineralization and the geochemical variations across the ore zone. A lithologic log and corresponding geochemical profile of CYR 5 are shown in Figure 4.

Two zones of thinly interbedded pyrite and mudstone near the top of the drill hole ( 36 and $46 \mathrm{~m}$ ) and three zones of massive pyrite $(70,73$, and $91 \mathrm{~m})$ are parallel to $S_{0}$. The most widespread alteration is pervasive sericitization of the mudstones immediately above the uppermost massive sulfide layer and continuing into the footwall rocks below the lowest massive sulfide layer (66-92 m). These rocks are unfoliated, and the sericite occurs in a felty, random orientation. A widely spaced cleavage locally disrupts $S_{0}$ through the lower part of this zone. Intense silicification together with sericite alteration of mudstone is prevalent immediately below the lowest massive sulfide layer, from 92 to $112 \mathrm{~m}$. This alteration, although spatially restricted, is texturally destructive and accompanied by extreme deformation of quartz and carbonate veinlets and other structural elements and the development of a strong foliation of fine-grained sericite and local development of an S-C fabric. Pressure shadows of chlorite surround some pyrite grains, indicating that some pyrite predates the latest deformation and metamorphism. Sericitic alteration and silicification, accompanied by a slight coarsening of the typically fine-grained muscovite and a color change from dark to light gray, is prevalent from 112 to $125 \mathrm{~m}$. Near the bottom of the drill hole, chlorite alteration is recognized macroscopically by a distinct darkening of the mudstone and microscopically by the predominance of fine-grained, slightly foliated 


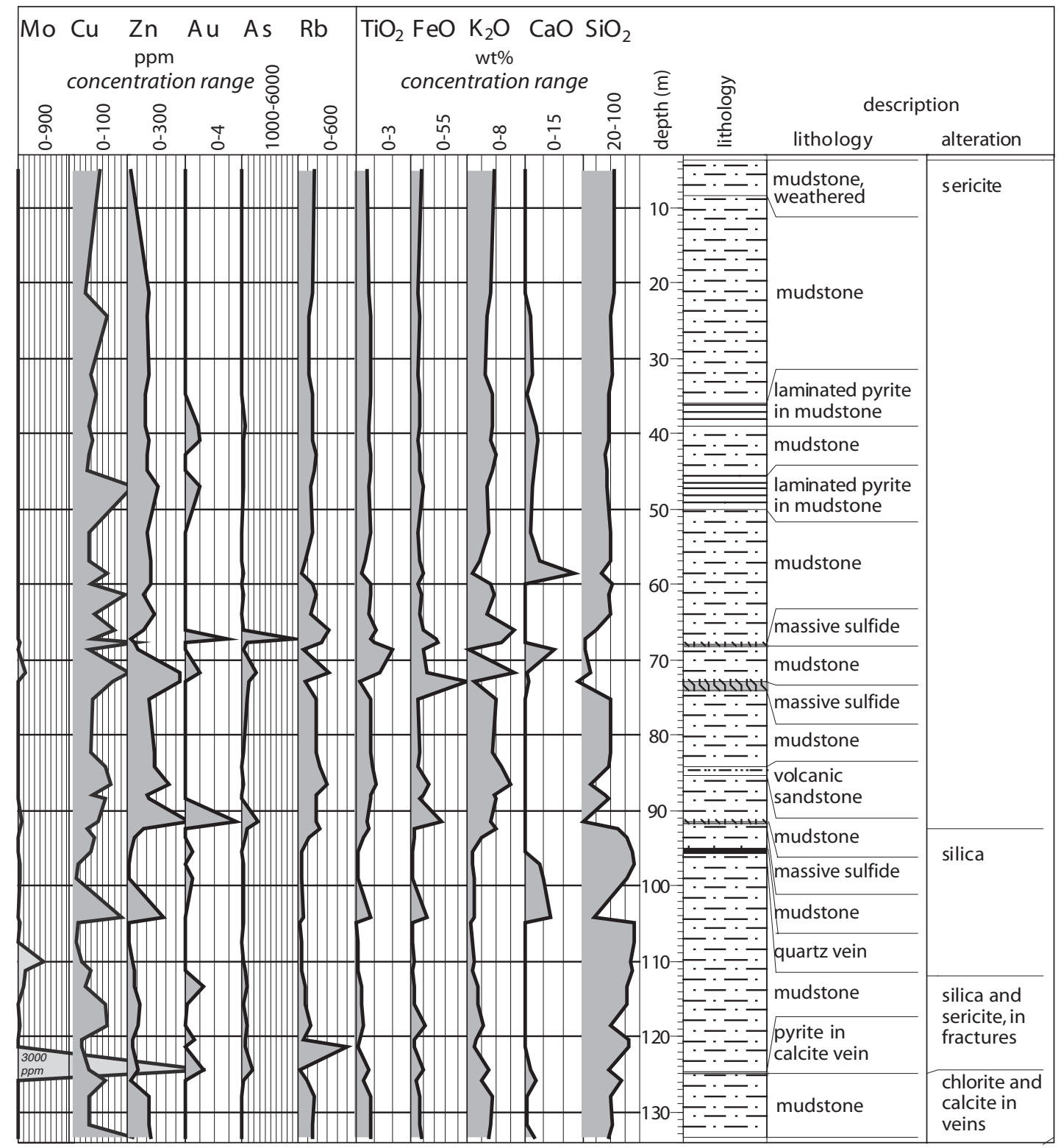

FIG. 4. Geochemical profiles and lithologic and alteration log of drill hole CYR 5, Russell mine.

chlorite rather than muscovite. Calcite in disseminated grains and veinlets typically accompanies chlorite alteration.

\section{Sulfide Mineralogy}

Drill core samples from both the Big Cut and Little Lead ore zones were examined using reflected light microscopy, scanning electron microscopy (SEM), and electron-microprobe analysis (EMP).

Much of the pyrite is concentrated along bedding layers $\left(\mathrm{S}_{0}\right)$ in siltstones and mudstones of the Tillery Formation, except where the host rock is locally deformed. Pyrite and fragments of volcanic rock also are part of the depositional sequence in virtually unaltered mudstones near the Russell dome. Sulfide minerals are finely disseminated along bedding planes and locally show textures interpreted to be graded bedding (Fig. 5a) and cut and fill sedimentary features. The sedimentary layers $\left(\mathrm{S}_{0}\right)$ are locally disrupted by small-scale folding and faulting (Fig. 3b) or are present as deformed, lens-shaped aggregates that are extended parallel to metamorphic foliation $\left(\mathrm{S}_{1}\right)$ (Fig. 3c) and represent disrupted and rotated bedding $\left(\mathrm{S}_{0}\right)$. Pyrite is also present in discrete veinlets that are parallel to the foliation $S_{1}$. Locally, these $S_{1}$-parallel veins are slightly deformed by open, low-amplitude folds indicating slight deformation after regional metamorphism. Barren stockwork veinlets of quartz and calcite cut altered rocks and postdate the pyritic beds.

SEM and reflected light images of mineralized samples from the Big Cut reveal two textural types of pyrite, referred to as stages 1 and 2 . Stage 1 pyrite consists of generally small, euhedral crystals (about $10-\mu \mathrm{m}$ diam) that contain many small cavities, on the order of $1 \mu \mathrm{m}$ in diameter, and some larger cavities (Fig. 5b), thus giving the grains a "spongy" 

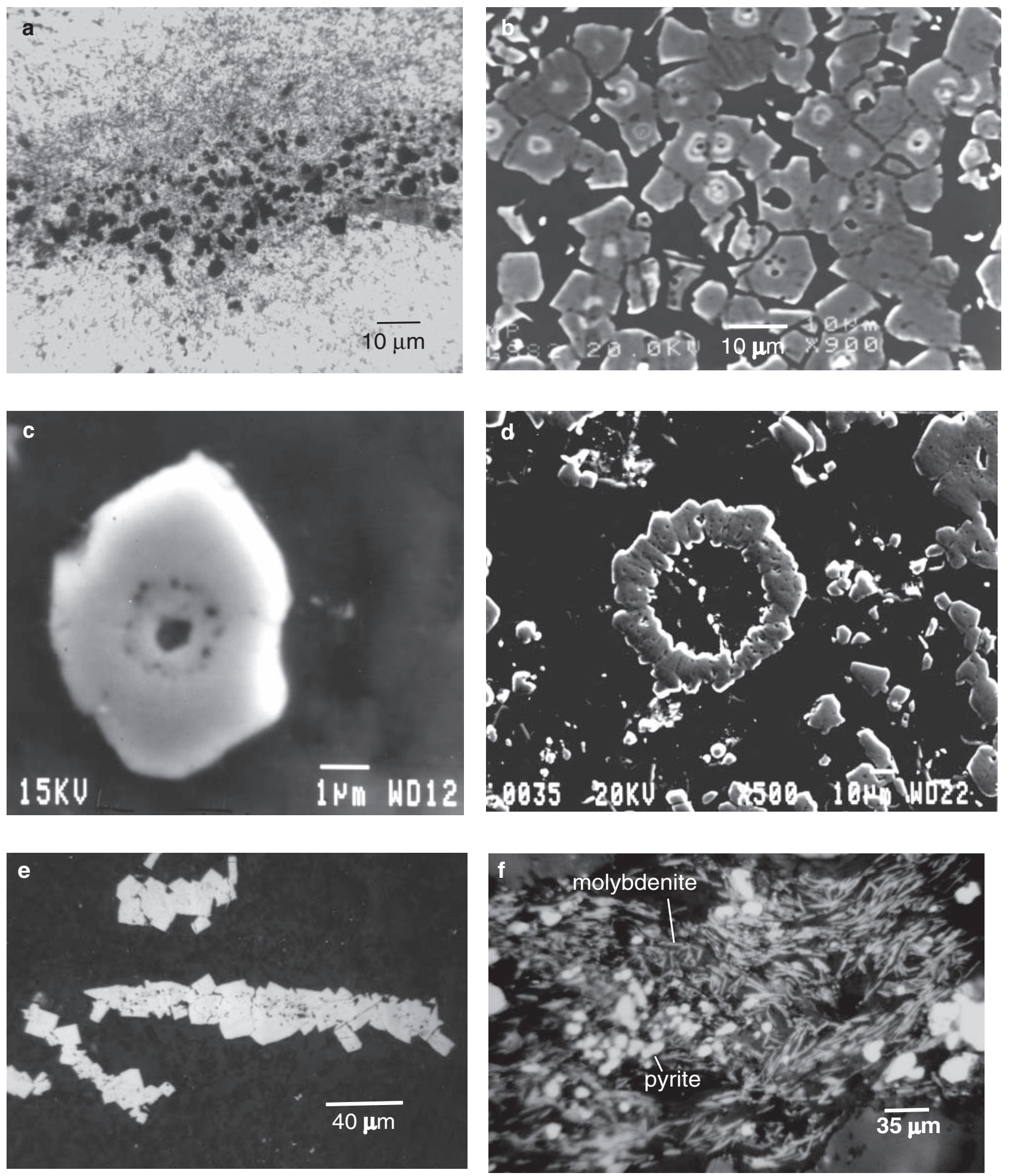

FIG. 5. Ore textures at the Russell mine. a. Polished section showing graded pyrite crystals (dark) interlayered with Tillery Formation mudstones. Drill-hole CYR 5, $50 \mathrm{~m}$. b. SEM image of pyrite crystals showing central cavities and stage 2 pyrite overgrowths. Drill hole CYR 5,72m. The white areas surrounding the cavities are enriched in arsenic. c. SEM image of pyrite crystal in Tillery Formation laminae showing central hole and symmetrical pattern of holes suggesting possible nucleation on or replacement of organic material. Drill hole CYR 5, $72 \mathrm{~m}$. d. SEM image of pyrite ring structure $60-\mu \mathrm{m}$ diam. Stage 1 cavities proposed to have formed by bacteria are the approximately $1-\mu \mathrm{m}$-size cavities within the structure. Note stage 2 , euhedral pyrite overgrowths. Drill hole CYR 5, $73 \mathrm{~m}$. e. Thin pyrite layers along disrupted bedding. Spongy (stage 1) pyrite is concentrated along the central parts of the crystals and is overlain by euhedral pyrite (stage 2). Drill hole CYR 5, 50 m. f. Pyrite and molybdenite in late syntectonic calcite-quartz vein. Pyrite grains are white, equant crystals; molybdenite grains area elongate crystals. Photomicrograph of polished section. Drill hole CYR 5, 125m. 
appearance. Some pyrite crystals have a geometric arrangement of smaller cavities surrounding a larger one (Fig. 5c). In other cases, circular features are present that consist of a ring of stage 1 pyrite crystals (Fig. $5 d$ ). Stage 2 pyrite consists of euhedral, idiomorphic overgrowths on stage 1 pyrite and is generally free of cavities or has just a few (Fig. 5e; Logan et al., 2001). Similar textures have been noted by Foley et al. (2001) at the Haile deposit in South Carolina. Some stage 2 pyrite contains inclusions of chalcopyrite and, locally, pyrrhotite aggregates containing arsenopyrite, cobaltite, galena, and sphalerite.

Individual grains were analyzed in six traverses from the core to the rim (10- $\mu \mathrm{m}$ steps) using an electron microprobe (data not shown). Although most of the data were near the detection limit of the microprobe, the results indicate that stage 1 pyrite generally contains less than 0.08 wt percent As but locally as much as 0.49 wt percent, with the highest amounts concentrated around the cavities (Fig. 5b). The maximum concentrations of other metals measured were $0.02 \mathrm{wt}$ percent Ag, 0.06 wt percent $\mathrm{Au}, 0.07$ wt percent $\mathrm{Co}, 0.02$ wt percent $\mathrm{Cu}, 0.03$ wt percent $\mathrm{Sb}, 0.02$ wt percent $\mathrm{Se}$, and 0.02 wt percent Zn. The stage 2 pyrite overgrowths have As-rich bands (avg 2-3 wt \% As; maximum 4.7 wt \% As) alternating with As-poor bands. Trace amounts of $\mathrm{Co}, \mathrm{Ni}, \mathrm{Ag}$, and $\mathrm{Zn}$ probably reflect small inclusions of niccolite and sphalerite in pyrite. Pyrrhotite contains up to 0.3 wt percent Ni and $0.2 \mathrm{wt}$ percent Co and, locally, shows pentlandite exsolution features parallel to $S_{1}$. Gold concentrations in stages 1 and 2 are low and variable, generally below the detection limit of the microprobe, but locally up to $600 \mathrm{ppm}$ without microscopic gold being visible. Silver telluride minerals (hessite and petzite) also have been reported from the Russell mine (Callahan et al., 1995). Rare molybdenite crystals occur parallel to $S_{1}$ and cut both textural types of pyrite (Fig. 5f), as do rare veinlets of chalcopyrite and calcite.

\section{Geochemistry}

Chemical analyses of drill core and surface rocks from the Russell deposit and surface samples of comparable unmineralized samples in the central Carolina slate belt are listed in Tables 1 and 2. Samples of the least-altered mudstone show the regional background and are listed in Table 2. Geochemical profiles, based on data from drill hole CYR 5, for key elements through the various ore and alteration zones are shown in Figure 6.

The highest Au values are associated with high As (Table 1) and massive sulfide layers (Fig. 1). Arsenic in the massive sulfide layers ranges up to 5,400 ppm. Ten bulk samples from sulfide-rich zones contain anomalous concentrations of gold (0.5-4 ppm). Five of the thickest zones and/or those with the highest Au concentrations are associated with pyrite layers that are parallel to $S_{0}$. Gold enrichment is also associated with a narrow zone of quartz veining in the siliceous and sericitic zone between 95 and $98 \mathrm{~m}$. These veins are syntectonic, related to the development of $\mathrm{S}_{1}$, and were probably contemporaneous with the growth of stage 2 pyrite. A late discordant syntectonic to posttectonic pyrite-calcite vein at $124.4 \mathrm{~m}$ contains $1.2 \mathrm{ppm} \mathrm{Au}$ and elevated concentrations of As and Mo. Surface samples from the ore zones in the Big Cut and the Parmer workings typically show Au concentrations from 0.2 to 9 ppm and As concentrations of 100 to greater than 300 ppm associated with ore zones (Kinkel, 1974).

Overall, base metal concentrations are low. Copper concentrations are about $100 \mathrm{ppm}$ in the massive sulfide zones (Table 1) which is about twice the regional background for the Tillery mudstones (Table 2). Zinc concentrations also are highest in massive sulfide zones, with concentrations ranging between approximately 270 and $330 \mathrm{ppm}$, about 10 times the regional background concentrations in Tillery mudstones. Zinc concentrations in the thinly laminated pyrite are only about two times the background values of the mudstone.

Comparing $\mathrm{Au}$ versus As values for the whole-rock samples (Table 1) indicates there is a general positive correlation between them; however, As in the massive sulfide layers ranges from 1,600 to $5,400 \mathrm{ppm}$, which is greater than 100 times the regional background concentration in unaltered mudstones. A high concentration (1,100 ppm) of As is also found in a late pyrite-calcite vein at $124 \mathrm{~m}$ (Fig. 5). Enrichment of $\mathrm{Au}$ and As occurs throughout CYR 5. Rocks above the ore zone are enriched in As by a factor of 10 relative to background values, whereas the laminated sulfide zone, the silicified zone, and the chlorite-carbonate zone are enriched 15 to 20 times the regional background. Surface sampling in the Russell Cut and the Parmer indicates As concentrations

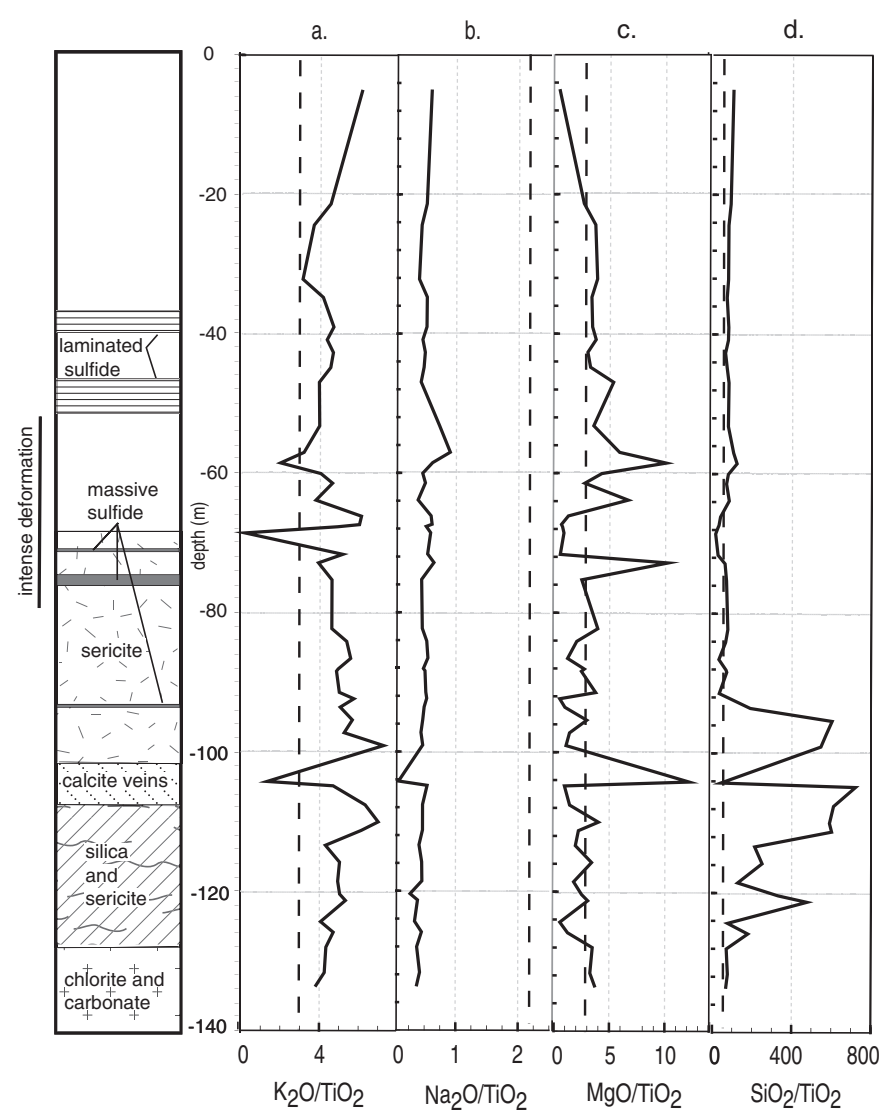

Fig. 6. Concentrations of selected trace and major element oxides from drill hole CYR 5 versus $\mathrm{TiO}_{2}$. The vertical dashed line represents the ratio of the background value for that element to $\mathrm{TiO}_{2}$ established from nonmineralized rocks (Table 2). Key geologic features of drill hole CYR 5 are shown on left. The ratios show overall depletion in $\mathrm{Na}$ throughout and enrichment of $\mathrm{K}$ and $\mathrm{Si}$ below massive and laminated sulfides zones. 
RUSSELL GOLD DEPOSIT, CAROLINA SLATE BELT, NORTH CAROLINA

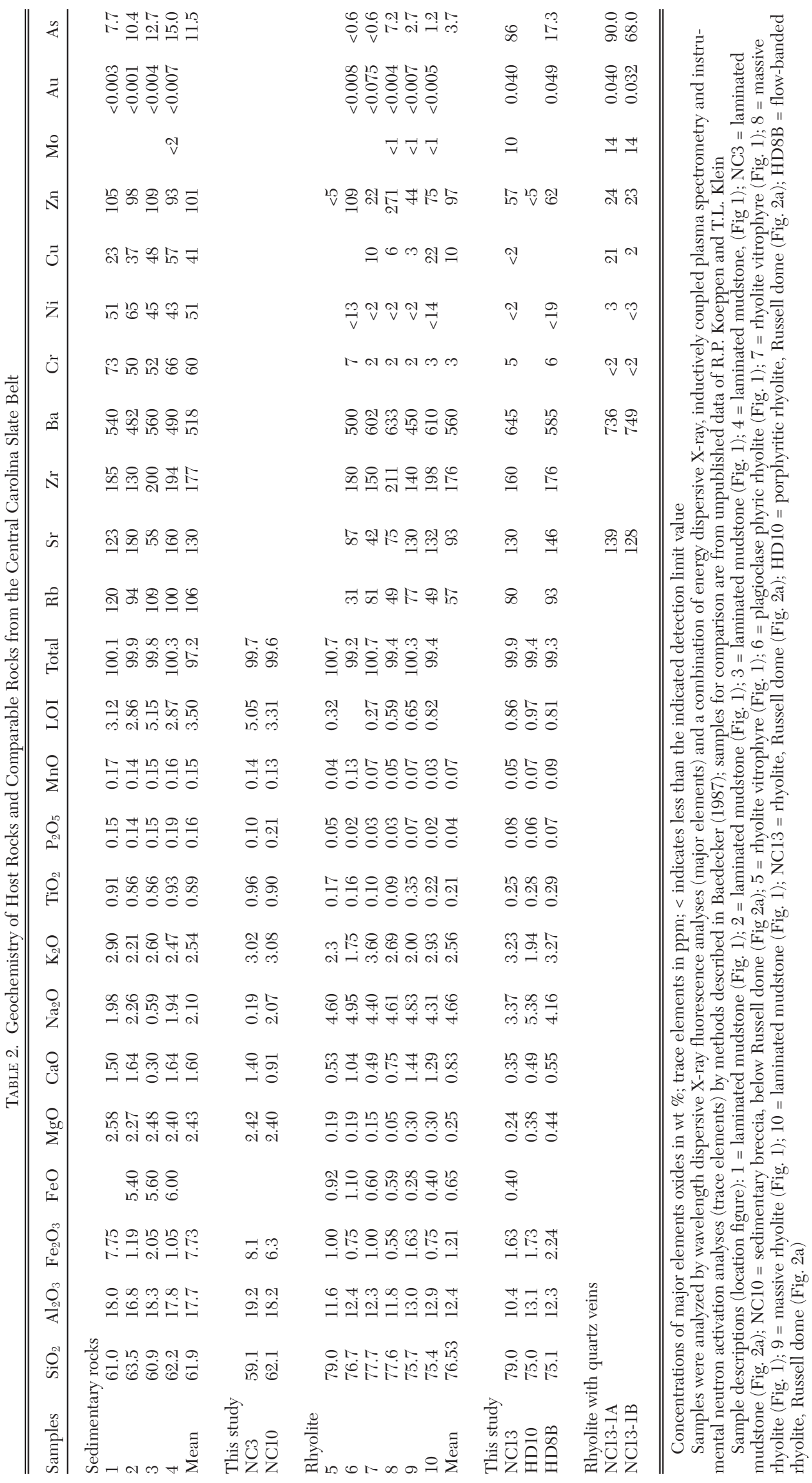


of 100 to greater than $300 \mathrm{ppm}$ associated with ore zones (Kinkel, 1974).

Within a massive sulfide layer a broad zone of calcite veining in silicified mudstone between 106 and $113 \mathrm{~m}$ contains high concentrations of Mo ranging from 33 to 476 ppm (Fig. 4). The highest concentration of Mo is found in a late pyrite-calcite vein at $124 \mathrm{~m}$ (3,300 ppm Mo) together with $1.2 \mathrm{ppm} \mathrm{Au}$. Rock samples taken from the Big Cut by Kinkel (1974) contained 15 to 25 ppm Mo, and low-level Mo enrichment in ore zones was recognized during past exploration at the Russell mine (E. Jones, Piedmont Minerals, pers. commun., 1998).

As seen in Figure 4, silicification is apparent below $90 \mathrm{~m}$. This increase in silica corresponds to a general decrease in concentrations of all major elements and nonmetallic trace elements. A strong positive correlation of $\mathrm{TiO}_{2}$ and $\mathrm{Zr}$ in the data from the drill hole suggests that these elements were relatively immobile and can be used to estimate relative gains and losses during alteration (Fig. 6). Most of the drill hole penetrates thinly laminated mudstone assumed to have had similar pre-alteration composition. The elemental gains and losses of key major elements relative to $\mathrm{TiO}_{2}$ are examined as a function of the depth of the sample in the hole (Fig. 6). Throughout the entire drill core $\mathrm{K}_{2} \mathrm{O} / \mathrm{TiO}_{2}$ is generally high, about 1.5 to 2 times the background; several narrow intervals in the silicified and sericitized rocks below the lowest massive sulfide layer (91 m) have significant additions of $\mathrm{K}_{2} \mathrm{O}$ (Fig. 6). In most of the drill hole, $\mathrm{Na}_{2} \mathrm{O} / \mathrm{TiO}_{2}$ is about 20 percent of background, except for narrow zones such as the silicified zone below the lowest massive sulfide $(91 \mathrm{~m})$ and in the interval containing late calcite veins at 100 to $106 \mathrm{~m}$, where the ratio is 2 to 6 times the background (Fig. 6b). The $\mathrm{MgO} / \mathrm{TiO}_{2}$ ratios are variable throughout the drill hole and the ratio is about 10 percent greater than background in the upper part of the drill hole and slightly higher in the chlorite-carbonate alteration zone near the bottom (Fig. 6). The $\mathrm{SiO}_{2} / \mathrm{TiO}_{2}$ values are near regional background levels to about $91 \mathrm{~m}$ where they increase to 100 to 600 times background (Fig 6d). The most intensely silicified rocks in the lower part of the drill hole below the lowest massive sulfide layer have $\mathrm{SiO}_{2}$ concentrations between 80 and 90 wt percent.

Two samples of mudstone directly underlying the rhyolite dome (NC 3 and NC 10) are similar to the mudstones overlying the Russell ore zone (Table 2). They are enriched in $\mathrm{K}_{2} \mathrm{O}$, somewhat depleted in $\mathrm{CaO}$, and have different $\mathrm{Na}_{2} \mathrm{O}$ concentrations.

Analyses of different rhyolite units from the Tillery Formation are given in Table 2. Comparisons with rhyolite from the Russell dome show that the dome is enriched to varying degrees in $\mathrm{Fe}_{2} \mathrm{O}_{3}, \mathrm{MgO}, \mathrm{K}_{2} \mathrm{O}$, As, $\mathrm{Au}$, Ba, Mo, and $\mathrm{Rb}$, compared to samples from the Tillery Formation, whereas $\mathrm{CaO}$ is depleted. Spherulitic rhyolite and thin quartz veins in the lower part of the dome are enriched in Au (32-49 ppb), As (17-90 ppm), and Mo (10-14 ppm). This suggests that the rhyolite was affected by hydrothermal fluids during the formation of the pyrite-bearing quartz veins in the lower part of the dome.

\section{Stable isotopes}

Stage 1 and 2 pyrite from within and near the ore zones and pyrite from the Tillery Formation, near the dome but away from ore, and disseminated pyrite in the dome were analyzed to determine their sulfur isotope ratios (Fig. 7). Conventional analytical techniques were used (Seal et al., 2000). Sampling was accomplished with a microdrill. Pyrite, both concordant with and discordant to bedding within and near the ore zones, has the lowest $\delta^{34} \mathrm{~S}$ values $(3.5-4.5 \%$ ), pyrite disseminated in the dome and in quartz veins cutting the dome has intermediate $\delta^{34} \mathrm{~S}$ values (5.1-5.4\%o), and pyrite disseminated in Tillery Formation mudstones away from ore has the highest $\delta^{34} \mathrm{~S}$ values (5.9-6.2\%o) as shown in Table 3.

The whole-rock $\delta^{18} \mathrm{O}$ values of the mudstones and volcanic rocks of the Albemarle Group ( 8-13\%) are similar to the whole-rock $\delta^{18} \mathrm{O}$ values of the mudstones of the Tillery Formation (7.4-10.6\%o; Fig. 8; and Feiss et al., 1993) and distinctly different from the $\delta^{18} \mathrm{O}$ values for fresh and altered rhyolites of the Uwharrie Formation (Feiss et al., 1993). In the Russell mine area, $\delta^{18} \mathrm{O}$ values for the altered and fresh rhyolites of the Russell dome and quartz in associated quartz veins (5.8-6.2\%o; Fig. 8) are also significantly lower than altered and unaltered mudstones of the Tillery Formation (7.4-11\%o; Table 3 and Fig. 8). On a regional scale, other studies have shown the $\delta 18 \mathrm{O}$ values in the fresh and altered underlying volcanic rocks of the Uwharrie Formation range from 0 to 6.2 per mil with the $\delta^{18} \mathrm{O}$ of altered rhyolites having lower values than the fresh rhyolites (Klein and Criss, 1988; Feiss et al., 1993). Mudstones from the lowest part of the overlying Cid Formation, about $5 \mathrm{~km}$ southwest of the Russell mine, have higher $\delta^{18} \mathrm{O}$ values (about 8.2 to $>13 \%$ ) than mudstones at the Russell mine.

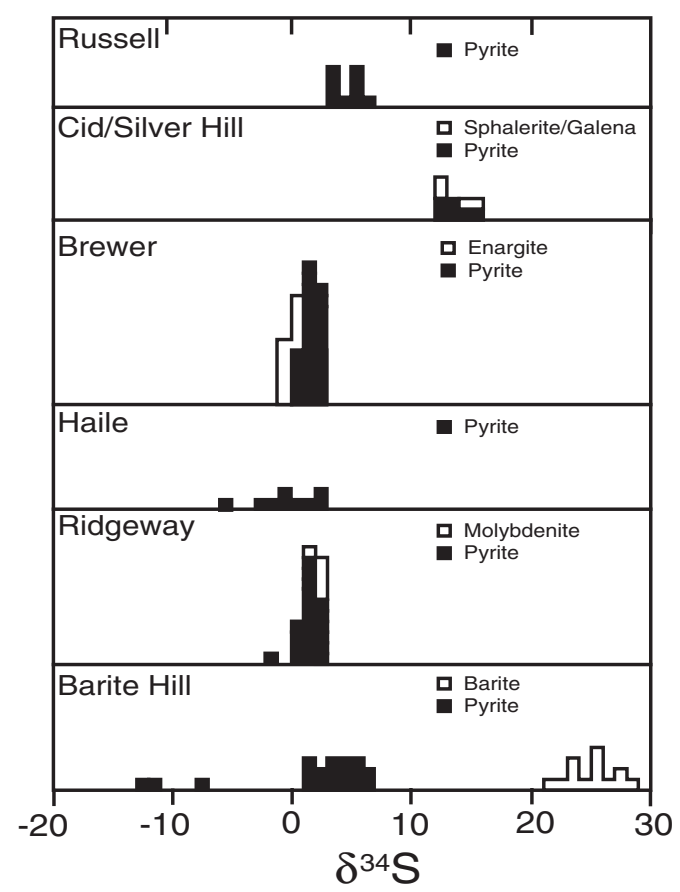

FIG. 7. $\delta^{34} \mathrm{~S}$ variation in pyrite and other minerals from precious metal deposits in the Carolina slate belt. $\delta^{34} \mathrm{~S}$ in sulfide minerals in most of the Carolina slate belt deposits ranges from $0-5.5 \%$ suggesting that sulfur in sulfide minerals was derived from a mixture of igneous sulfur and seawater-derived sulfur. High sulfur values such as at Barite Hill and in the Cid district are consistent with derivation by thermochemical reduction of early Paleozoic seawater sulfate. Data for the Barite Hill, Brewer, Haile, and Ridgeway mines are from Seal et al. (1997, 2001); other data are from Table 3. 
TABLE 3. Stable Isotope Data and Sample Descriptions

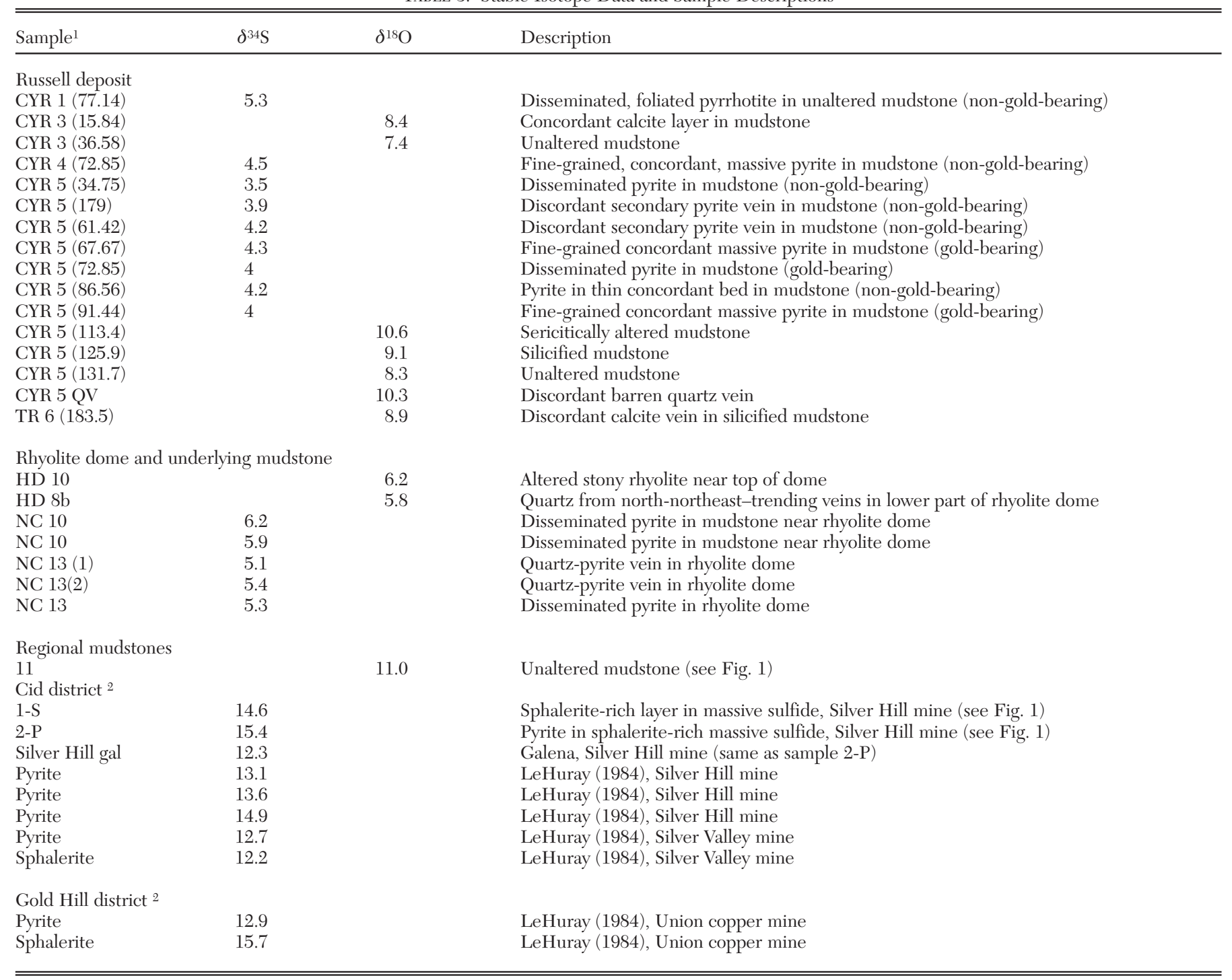

Oxygen results are reported relative to SMOW standard; sulfur results are relative to CDT standard

${ }^{1}$ Locations for samples from the vicinity of the Russell mine are in Figure 2a unless otherwise shown in parentheses in the description; Russell deposit samples from drill core; drill hole number is followed by depth in meters in parentheses

${ }^{2}$ Analyses from other massive sulfide metal deposits in the Carolina slate belt

\section{Discussion}

\section{Age relationships}

The local stratigraphy indicates that the west-dipping Tillery Formation conformably overlies the Uwharrie Formation, which crops out to the east of the Russell mine (Stromquist and Henderson, 1985), and in turn is overlain by the Cid Formation exposed to the west. The best age data for the Uwharrie Formation are between $558 \pm 8$ and $568 \pm 6$ $\mathrm{Ma}$, based on $\mathrm{U}-\mathrm{Pb}$ zircon ages of the Uwharrie volcanic sequence (Kozuch, 1994). The age of rhyolite from the lower Tillery Formation near Asheboro, North Carolina, about 30 $\mathrm{km}$ north of the study area, is $554 \pm 14 \mathrm{Ma}$ (Kozuch, 1994), based on $\mathrm{U}-\mathrm{Pb}$ zircon age constraints. Rhyolite from the upper part of the Tillery Formation at Morrow Mountain, about $15 \mathrm{~km}$ southeast of the mine area, has a U-Pb zircon age of $539 \pm 6 \mathrm{Ma}$ (Ingle, 1999). Rhyolite from the overlying Cid Formation has a U-Pb zircon age of $542 \pm 14 \mathrm{Ma}$ (Kozuch, 1994). These ages are consistent with the occurrence of latest Proterozoic Ediacaran fauna in basal mudstones of the Cid Formation (Gibson et al., 1984). Crystallization ages of the host volcanic rocks of the Persimmon Fork Formation, for the Haile, Brewer, and Ridgeway deposits range from $550 \pm 3 \mathrm{Ma}$ to $556 \pm 2 \mathrm{Ma}$ (Ayuso et al., 2005). The best estimate of the age of the host rocks of the Russell deposit is that of the lower Tillery Formation (554 Ma). This lies in the interval of ages determined for the larger deposits in South Carolina.

The age of dominant metamorphism in this part of the Carolina slate belt is approximately $456 \pm 2 \mathrm{Ma}$, based on the ${ }^{40} \mathrm{Ar} /{ }^{39} \mathrm{Ar}$ studies of the Tillery Formation near Asheboro, North Carolina, by Offield et al. (1995). Samples from the 


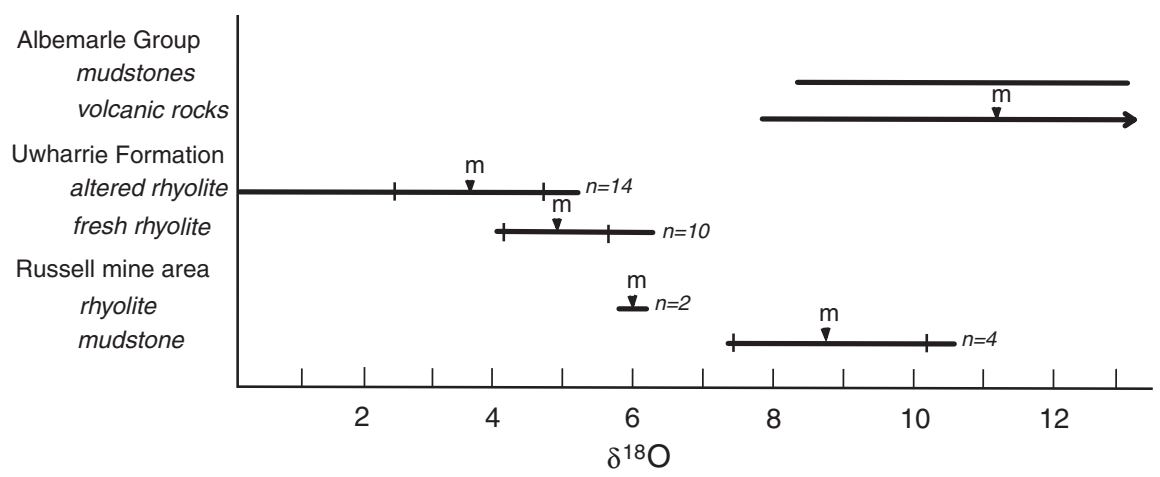

FIG. 8. $\delta^{18} \mathrm{O}$ variation in rock units associated with mineral deposits at the Russell mine. $\delta^{18} \mathrm{O}$ values for the fresh rhyolites from the Uwharrie Formation are similar to rhyolite from the Russell dome. Mudstone host rock at the Russell mine lies within the $\delta^{15} \mathrm{O}$ range of typical mudstones from the Albemarle Group. Data for Uwharrie Formation are from Klein and Criss (1988), the Albemarle Group from Feiss and Weslowski (1986) and the Russell mine from this study. Abbreviations: $(\mathrm{m})=$ the mean value, $(\mathrm{n})=$ the number of samples represented and the vertical bars on data ranges are one standard deviation from the mean. Distribution statistics and (or) raw data were not available for data of Feiss and Weslowski (1986).

Tillery Formation near the Russell mine have a probable age of metamorphism of $455 \mathrm{Ma}$, based on ${ }^{40} \mathrm{Ar} /{ }^{39} \mathrm{Ar}$ ages of sericite (Noel et al., 1988). The regional metamorphism is thus Taconian in age. In this part of the Carolina slate belt, only one period of metamorphism has been recognized. Elsewhere in the Carolina slate belt, Acadian and Alleghenian metamorphism is recognized; however, deformation related to these later events appears to be confined to discrete shear zones (Offield, 1994).

In the Russell deposit, veins containing molybdenite, quartz, calcite, REE-rich apatite, and chalcopyrite were introduced after development of the metamorphic fabric. Molybdenite was dated at the Haile deposit (Stein et al., 1996) using Re-Os and gave an age of about 555 to $585 \mathrm{Ma}$ that was interpreted to indicate the original age of the oreforming system. This is similar to the best age for the rhyolites of the Uwharrie Formation (Kozuch, 1994) and the best age for the Russell deposit. Molybdenite has not been dated at the Russell deposit; however, textural constraints indicate it was introduced to its present location after recrystallization of the latest pyrite (stage 2). Calcite crystals in some of the postmetamorphic veins exhibit cockscomb textures that indicate open-space deposition in a low-strain environment. Zoned postmetamorphic quartz veins containing potash feldspar with cockscomb texture also occur in the nearby Riggon Hill prospect (Fig. 2a). The ${ }^{40} \mathrm{Ar} /{ }^{39} \mathrm{Ar}$ spectrum of this feldspar reflects cooling after a thermal event that occurred prior to 387 Ma (M. Kunk, U.S. Geological Survey, written commun., 1999). This Acadian age, being considerably younger than the widespread Taconian metamorphism in this part of the Carolina slate belt, suggests that a late hydrothermal event of this age may have remobilized previously deposited minerals such as molybdenite and formed the REE-bearing apatite.

\section{Bimodal volcanism}

The sediment-hosted Russell deposit is closely related to mafic and felsic bimodal volcanism. Recognition of mafic volcanic rock fragments in mudstones in the ore zones at the mine suggests that the source rock area included mafic volcanic rocks. Metabasalts in the Tillery Formation are exposed about $1.6 \mathrm{~km}$ to the west and north of the Russell mine and near the Coggins mine to the south (Conley, 1962b; Stromquist et al., 1971). These metabasalts typically show relict hyaloclastic breccia textures consistent with subaqueous extrusion and were a likely source for the mafic rock fragments within the siltstones. Neither the Russell dome nor the sulfide deposit is directly dated. However, rhyolite in the dome appears to be coeval with the massive sulfide lenses at the Russell mine; fragments of spherulitic rhyolites are common in the mudstone matrix, and the rocks of the Tillery Formation and from the rhyolite dome have similar geochemical enrichments and depletions.

\section{Stable isotopes}

The range of $\delta^{34} \mathrm{~S}$ values for pyrite from the Russell mine is similar to that of massive pyrite from Barite Hill, South Carolina, (Seal et al., 2001) and slightly higher than that of pyrite from the Haile, Brewer, and Ridgeway, deposits in South Carolina, suggesting that they all had a similar sulfur source. Samples from the nearby base metal-rich sulfide minerals from massive sulfide deposits in the Cid and Gold Hill districts, North Carolina, and samples from the Barite Hill mine (Fig. 1) have much higher ${ }^{34} \mathrm{~S}$ values consistent with derivation of sulfur by thermochemical reduction of early Paleozoic seawater sulfate (Table 3; Seal et al., 2000).

At the Russell mine, the source of sulfur is thought to have been hydrothermal fluids carrying a mixture of igneous sulfur $(\sim 0 \%)$ and seawater-derived sulfur from the mudstones and is similar to that proposed for other Carolina slate belt massive sulfide deposits in South Carolina (Seal et al., 2001). The similarity of $\delta^{34} S$ values of pyrite in ore samples and associated rocks, and pyrite in quartz veins in the nearby rhyolite dome suggests they had a similar source of sulfur.

Klein and Criss (1988) concluded that volcanic, sedimentary, and intrusive rocks in the Uwharrie Formation wholly or partially reequilibrated with contemporaneous meteoric water, a feature that is consistent with subaerial deposition. They also found that many of the hydrothermal mineral deposits, including the Snow Camp, Hoover Hill, Sawyer, Star, and Iola deposits were formed by fluids dominated by 
meteoric water. In contrast, sedimentary and volcanic rocks of the overlying Albemarle Group, including the Tillery Formation, interacted with seawater and a gap exists between the $\delta^{18} \mathrm{O}$ values of whole rocks from the Uwharrie Formation and those from the Albemarle group (Feiss et al., 1993) that is demonstrated at the Russell mine (Fig. 8). Oxygen isotope ratios of mudstones from the lower part of the overlying Cid Formation exposed in the Jacobs Creek quarry are substantially higher and may represent end-member marine sediment values. The whole-rock $\delta^{18} \mathrm{O}$ values at the Russell mine are in the range considered by Feiss et al. (1993) to mark the transition from a subaerial to a marine depositional environment. This scenario is consistent with the development of a back-arc basin that was filled by sediments of the Albemarle Group. They also observed that the change in depositional environment was accompanied by a corresponding change in mineralization style from epithermal disseminated gold and pyrite deposited in the subaerial volcanic rocks to kurokotype deposits deposited in the marine sedimentary rocks.

\section{Pyrite textures}

Textural relations suggest that primary sulfide minerals of the Russell mine were deposited syngenetically or diagenetically under subaqueous conditions and were later recrystallized, perhaps accompanied by the introduction of additional metals. The apparent graded bedding of pyrite crystals (Fig. 5a) and local cut-and-fill structures are interpreted to be a primary feature reflecting precipitation of sulfide minerals from sulfur-rich submarine hot springs. Paragenetically early pyrite containing remnant colloform and crustiform textures of pyrite associated with ore minerals at other deposits in the Carolina slate belt have been interpreted as evidence that mineralization was coeval with the deposition of the host rocks (Foley et al., 2001).

The presence of abundant, similar-sized cavities in or near the center of stage 1 pyrite crystals suggests that pyrite growth was partly controlled by nucleation on foreign matter that has since been removed. The presence of arsenic-rich halos around the cavities (Fig. 5b) further suggests that whatever initially filled the holes was involved in concentrating arsenic. We propose that organic material, probably micronsized bacteria, may have been important in the initial deposition of pyrite. Bacteria are the right size, can precipitate sulfides, and are commonly abundant in marine sediments. Experimental studies have shown convincingly the ability of bacterial spores to nucleate gold (Watterson et al., 1984; Brooks and Watterson, 1992), silver (Mullen et al., 1989), and other metals (Fortin et al., 1997) on or within cell walls. Parduhn et al. (1985) also showed that some bacteria develop a tolerance for toxic elements. Zierenberg and Schiffman (1990) documented replacement and overgrowth of bacterial filaments that selectively precipitated silver, arsenic, and copper. They noted that bacteria are preserved by pseudomorphic replacement and overgrowth by sulfide and sulpharsenide minerals. Bacteria that derive their energy from chemosynthesis are common at sea-floor hydrothermal vents of the type that are considered to have deposited sulfides in the Russell deposit. Such bacterial populations can create physiochemical microenvironments that can influence both mineral and trace element accumulation (Juniper et. al.,
1986; Juniper and Fouquet, 1988). Some textures observed at the Russell mine, such as ring structures with a diameter of about $60 \mu \mathrm{m}$ (Fig. $5 \mathrm{~d}$ ), are too large to be related to a single bacterium. However, the micron-sized cavities in the wall of the ring suggest that the overall structure could be the fossil remains of a bacteria-laden, filament or mucus-lined tube (Juniper and Fouquet, 1988, Juniper et al., 1992; Juniper and Tebo, 1995). Little et al. (1997) demonstrated experimentally that biodeposited manganese oxide deposits could form ring structures of comparable size. Pyrite also is present as platy features interlayered with disrupted bedding as shown in Figure 5e. These contain stage 1 spongy pyrite with euhedral stage 2 overgrowths. We cannot rule out that the pyrite textures represent inclusions of iron hydroxide particles, fluid inclusions, or minerals that were subsequently dissolved, although the regular geometry suggests a biogenic origin.

Pyrite in framboids, some with central cavities, also suggests that some of the pyrite in the Russell deposit was nucleated on or replaced organic matter on the sea floor. Similar textures are well documented in kuroko- and Besshi-type deposits (Eldridge et al., 1983; Yui, 1983).

\section{Gold content}

It is easier to make a case for stage 1 pyrite being deposited on the ocean floor than it is for the pyrite to contain primary $\mathrm{Au}$. The $\mathrm{Au}$ is present in stage 1 pyrite near the limit of detection by the electron microprobe and it correlates with As concentrations which, in turn, are texturally zoned about the stage 1 voids as seen in Figure 5b. Spongy pyrite also contains free gold within the cavities, which may be interpreted as either a primary or secondary feature.

\section{Alteration}

Sericite alteration, the result of potassium enrichment, is widespread in the deposit. Above and within the zone of massive and laminated sulfide deposition, sericite is randomly oriented, and pyrite grains within the syngenetic layers show chlorite-filled pressure shadows, possibly resulting from the synmetamorphic reaction of preexisting bedded and disseminated pyrite and sericite. These features support the interpretation that the potassium metasomatism associated with the bedding parallel sulfides occurred prior to regional Taconian metamorphism and deformation.

Extensive silicification below the massive sulfide zone occurs in a shear zone that deforms all structural elements, including quartz and carbonate veins. This zone of silicification and deformation is similar to those found in the five other "leads" that correspond to highly deformed fold crests and is clearly epigenetic. Hydrothermal fluids focused along these fold crests caused extensive silicification parallel to $S_{1}$ during what we interpret as Taconian deformation. The development of these high strain zones clearly postdates the deformed bedding parallel sulfide accumulations.

\section{Conclusions}

The Russell deposit is interpreted to have formed as a syngenetic, exhalative, gold-rich massive sulfide deposit hosted by the late Proterozoic laminated mudstones of the Tillery Formation. It was, in part, remobilized by hydrothermal fluids during Ordovician syntectonic regional deformation into 
northeast-trending, structurally controlled zones that developed along attenuated, asymmetric, east-verging anticlinal folds that formed the multiple ore leads.

Two morphologies of pyrite are present. Stage 1 pyrite is characterized by $10-\mu \mathrm{m}$ euhedral crystals containing cavities about $1 \mu \mathrm{m}$ in diameter that are interpreted to result from nucleation of the sulfides on bacteria. This texture is most abundant in the centers of thin pyrite layers that are interbedded with the layered mudstones. Locally, the cavities are so abundant as to give the pyrite a "spongy" appearance. The enrichment and zonation of As in stage 1 pyrite suggests that it is a primary syngenetic feature of the deposit, and the geochemical association of $\mathrm{Au}$ with As suggests that it too was introduced early in the paragenesis. The lack of primary breccia features in the ore and the predominance of $\mathrm{Zn}$ over $\mathrm{Cu}$ suggest a low-temperature, possibly distal setting. Stage 2 pyrite is present as euhedral overgrowths on Stage 1 pyrite. Stage 2 pyrite contains growth layers that are enriched in As that formed during Ordovician Taconian metamorphism and deformation associated with the development of $S_{1}$ foliation. Late syn- to posttectonic quartz veins are enriched in Mo.

The deposit is associated with bimodal rhyolite-basalt volcanism. A nearby rhyolite dome appears to be coeval with the massive sulfides; they are closely spatially associated and on the same regional strike, they were both deposited during Tillery Formation sedimentation, stratigraphically near the base of the Tillery Formation, and the ore-hosting rock types and rocks from the rhyolite dome have similar geochemical enrichments and depletions. Geochemical and sulfur isotope data suggest that the rhyolite was a possible source of the heat and some of the metals that formed the deposit. Most of the gold production from gold-rich VMS deposits has been from deposits with a close spatial and temporal association with felsic volcanic successions (Barrie and Hannington, 1999; Hannington et al., 1999).

The dominance of what we interpret to be premetamorphic sericitic alteration associated with early syngenetic sulfide layers at the Russell deposit, the low base metal content of the syngenetic sulfide layers, and the geochemical association of $\mathrm{Au}$ and $\mathrm{As}$ are similar to the Haile and Ridgeway deposits in northern South Carolina (Feiss et al., 1993; Ayuso et al., 1997, 2005; Clark et al., 1999; Foley et al., 2001). Together with massive sulfide deposits at Barite Hill, South Carolina, and in the Cid and Gold Hill districts, North Carolina, may represent two end members of submarine exhalative mineralization in the Carolina slate belt, namely base metal-rich, kuroko-type deposits (Barite Hill, Gold Hill, and the Cid district) and base metal-poor, gold-rich deposits (Haile, Ridgeway and Russell).

\section{Acknowledgments}

Piedmont Minerals kindly provided access to exploration drill core and data and permission to publish the results of our study. In particular, we would like to thank Earl Jones of Piedmont Minerals for his cooperation. Special thanks are extended to the many geologists with whom we have sought advice about aspects of the geology and origin of this deposit. They include Chris Dail, David Emmons, Mark Hannington, Irving Kiff, Randy Koski, Dennis LaPoint, Tom Kleeburg, John Madry, and Joe Worthington. Dennis LaPoint suggested that the Russell mine would be a good place to investigate rock-ore relationships in the central Carolina slate belt. Thoughtful reviews contributed by Robert Ayuso, David Craw, Mark Hannington, Robert Luedke, Ian Ridley, and Stuart F. Simmons substantially improved the manuscript.

\section{REFERENCES}

Ayuso, R.A., Seal, R.R. II, Foley, N.K., Offield, T.W., and Kunk, M.J., 1997, Genesis of gold deposits in the Carolina slate belt, USA: Regional constraints from trace element, $\mathrm{Pb}-\mathrm{Nd}$ isotopic variations, and ${ }^{40} \mathrm{Ar} /{ }^{39} \mathrm{Ar}$ geochronology [abs.]: Geological Society of America Abstracts with Programs, v. 29, p. A-60

Ayuso, R.A., Wooden, J.L., Foley, N.K., Seal, R.R., II, and Sinha, A.K., 2005 , U-Pb zircon ages and $\mathrm{Pb}$ isotope geochemistry of gold deposits in the Carolina slate belt of South Carolina: Economic Geology, v. 100, p. 225-252.

Baedecker, P.A., 1987, Methods for geochemical analysis: U.S. Geological Survey Bulletin 1770, 132 p.

Barrie, C.T., and Hannington, M.D., 1999, Classification of volcanic-associated massive sulfide deposits based on host-rock composition: Reviews in Economic Geology, v. 8, p. 1-11.

Bell, H., III, 1982, Strata-bound sulfide deposits, wall-rock alteration, and associated tin-bearing minerals in the Carolina slate belt, South Carolina and Georgia: Economic GeOLOGY, v. 77, p. 294-311.

Brooks, R.R., and Watterson, J.R., 1992, The noble metal biogeochemistry of microorganisms: in Brooks, R.R., ed., Noble metals and biological systems; Their role in medicine, mineral exploration, and the environment, Boca Raton, Florida, CRC Press, p. 159-196.

Callahan, J.E., Craig, J.R., and Solberg, T.N., 1995, Telluride mineralization of the southeastern United States: Southeastern Geology, v. 35, p. 139-151.

Carpenter, R.H., Odom, A.L., and Hartley, M.E., 1982, Geochronological investigation of the Lincolnton metadacite, Georgia and South Carolina, in Bearce, D.N., Black, W.W., Kish, S.A., and Tull, J.F., eds., Tectonic studies in the Talladega and Carolina slate belts, southern Appalachian orogen: Geological Society of America Special Paper 191, p. 145-152.

Clark, S.H.B, Gray, K.J., and Back, J.M., 1999, Geology of the Barite Hill gold-silver deposit in the southern Carolina slate belt: ECONOMIC GEOLOGY, v. 94, p. 1329-1346.

Conley, J.F., 1962a, Geology of the Albemarle quadrangle, North Carolina: North Carolina Department of Conservation and Development, Division of Mineral Resources Bulletin 75, 26 p.

$1962 b$, Geology and mineral resources of Moore County: North Carolina Department of Conservation and Development, Division of Mineral Resource Bulletin 76, 40 p.

Eldridge, C.S., Barton, P.B., Jr., and Ohmoto, H., 1983, Mineral textures and their bearing on formation of Kuroko orebodies: ECONOMIC GEOLOGY MONOGRAPH 5, p. 241-281.

Feiss, G.P., 1982, Geochemistry and tectonic setting of the volcanics of the Carolina slate belt: ECONOMIC GEOLOGY, v. 77, p. 273-293.

1988, Gold mineralization in the southern Appalachian piedmontPardee and Park redivivius, in Kisvarsanyi, G. and Grant, S.K, eds., North American Conference on Tectonic Control of Ore Deposits and the Vertical and Horizontal Extent of Ore Systems, Proceedings Volume: Rolla, Missouri, University of Missouri-Rolla, p. 491-500.

Feiss, G.P., and Wesolowski, D.J., 1986, Oxygen isotopic evidence for the interaction of meteoric-hydrothermal waters with granites and subaerial volcanics in pyrophyllite/Au deposits of the Carolina slate belt [abs.]: Geological Society of America Abstracts with Programs, v. 18, p. 600.

1990, The tectonic significance of the Uwharrie/Albemarle contact in the central Carolina volcanic slate belt (CVSB): Isotopic and chemical evidence [abs.]: Geological Society of America Abstracts with Programs, v. 22, p. 14.

Feiss, G.P., Vance, R.K., and Wesolowski, D.J., 1993, Volcanic rock-hosted gold and base metal mineralization associated with Neoproterozoic-Early Paleozoic back-arc extension in the Carolina terrane, southern Appalachian Piedmont: Geology, v. 21, p. 439-442.

Foley, N., Ayuso, R.A., and Seal, R.R., II, 2001, Remnant colloform pyrite at the Haile gold deposit, South Carolina: A textural key to genesis: EcoNOMIC GEOLOGY, v. 96, p. 891-902. 
Fortin, D., Ferris, F.G., and Beveridge, T.J., 1997, Surface-mediated mineral development by bacteria, in Banfield, J.F., and Nealson, K.H., eds., Geomicrobiology: interactions between microbes and minerals: Reviews in Mineralogy, v. 35, p. 160-180.

Franklin, J.M., Sangster, D.M., and Lydon, J.W., 1981, Volcanic-associated massive sulfide deposits: Economic Geology $75^{\text {тн }}$ AnNiversary Volume, p. $485-627$.

Gibson, G.G., Teeter, S.A., and Fedonkin, M.A., 1984, Ediacarian fossils from the Carolina slate belt, Stanly County, North Carolina: Geology, v. 12, p. 387-390.

Goldsmith, R., Milton, D.J., and Horton, J.W., Jr., 1988, Geologic map of the Charlotte $1^{\circ}$ x $2^{\circ}$ quadrangle, North Carolina and South Carolina: U.S. Geological Survey Miscellaneous Investigations Map I-1251-E, 1:250,000.

Guthrie, V.N., 1980, Geology of the Dorn mine, McCormick, South Carolina: Unpublished M.S. thesis, University of Georgia, $127 \mathrm{p}$.

Hannington, M.D., Poulsen, K.H., Thompson, J.F.H., and Sillitoe, R.H., 1999, Volcanogenic gold in the massive sulfide environment: Reviews in Economic Geology, v. 8, p. 325-356.

Hayward, N., 1992, Controls on syntectonic replacement mineralization in parasitic antiforms, Haile gold mine, Carolina slate belt: ECONOMIC GEOLOGY, v. 87 , p. 91-112.

Indorf, C.P., 1981, The Silver Hill zinc deposit and associated deposits, central North Carolina: ECONOMIC GEOLOGY, v. 76, p. 1170-1185.

Ingle, S.P., 1999, Age and tectonic significance of the Uwharrie Formation and Albemarle Group, Carolina slate belt: Unpublished MS thesis, Gainesville, University of Florida, 96 p.

Juniper, S.K., and Fouquet, Y., 1988, Filamentous iron-silica deposits from modern and ancient hydrothermal vents: Canadian Mineralogist, v. 26, p. $859-869$

Juniper, S.K., and Tebo, B.M., 1995, Microbe-metal interactions and mineral deposition at hydrothermal sites, in Karl, D.M., ed., The microbiology of deep-sea hydrothermal vents: CRC Press, p. 219-253.

Juniper, S.K., Thompson, J.A.J., and Calvert, S.E., 1986, Accumulation of minerals and trace elements in biogenic mucus at hydrothermal vents: Deep-Sea Research, v. 33, p. 339-347.

Juniper, S.K, Jonasson, I.R., Tunnicliffe, Verena, and Southward, A.J., 1992, Influence of a tube-building polychaete on hydrothermal chimney mineralization: Geology, v. 20, p. 895-898.

Kerr, W.C., and Hanna, G.B., 1888, Ores of North Carolina: North Carolina Geological Survey Bulletin 2, p. 248-251.

Kinkel, Jr., A.R., 1974, Geochemical sampling at the Russell mine, Montgomery County, North Carolina: U.S. Geological Survey Open File Report, $4 \mathrm{p}$.

Klein, T.L., and Criss, R.E., 1988, An oxygen isotope and geochemical study of the meteoric-hydrothermal systems at Pilot Mountain and other selected localities, Carolina slate belt: ECONOMIC GEOLOGY, v. 83, p. 801-821.

Klein, T.L., Cunningham, C.G., Logan, M.A.V., Seal, R.R. II, and Offield, T.W., 1998, Russell gold mine-A submarine exhalative gold deposit in the Carolina slate belt [abs.]: Geological Society of America Abstracts with Programs, v. 30 , p. 368.

Koeppen, R.P. and Klein, T.L., 1989, Caraway-Back Creek volcanic center, central slate belt, North Carolina, in K.S. Schindler, ed., USGS Research on Mineral Resources-1989: U.S. Geological Survey Circular 1035, p. $40-41$

Kozuch, M., 1994, Age, isotopic, and geochemical characterization of the Carolina slate and Charlotte belts: implications for stratigraphy and petrogenesis: Unpublished M.S. thesis, Gainesville, Florida, University of Florida, $114 \mathrm{p}$.

Laney, F.B., 1910, The Gold Hill mining district of North Carolina: North Carolina Geological Survey Bulletin 21, $137 \mathrm{p}$.

LeHuray, A.P., 1984, Lead and sulfur isotope systematics in some sulfide deposits of the Piedmont and Blue Ridge provinces of the southern Appalachians, U.S.A.: U.S. Geological Survey Open-File Report 84-112, 428 p.

Lindgren, W., 1933, Mineral deposits (4 $4^{\text {th }}$ ed.): New York, McGraw-Hill Book Co., Inc., $930 \mathrm{p}$

Little, B.J., Wagner, P.A., and Lewandowski, Z., 1997, Spatial relationships between bacteria and mineral surfaces, in Banfield, J.F., and Nealson, K.H., eds., Geomicrobiology: interactions between microbes and minerals: Reviews in Mineralogy, v. 35, p. 123-159.

Logan, A.V., Klein, T.L., and Cunningham, C.G., 2001, Multistage pyrite growth at the Russell mine; a low metamorphic grade VMS deposit in the southern Appalachians, North Carolina, USA [abs.]: North American
Mineral Symposium, Extended Abstracts volume, GAC-MAC St. John's Annual Meeting, p. 92-94

Mullen, M.D., Wolf, D.C., Ferris, F.G., Beveridge, T.J., Flemming, C.A., and Bailey, G.W., 1989, Bacterial sorption of heavy metals: Applied and Environmental Microbiology, v. 55, p. 3143-3149.

Nelson, L.G., and Feiss, P.G., 1990, The Sam Christian gold mine (Montgomery County, NC) in the Uwharrie Formation of the Carolina volcanic slate belt [abs.]: Geological Society of America, Abstracts with Programs, v. 22, p. 53.

Nitze, H.B.C., and Hanna, G.B., 1896, Gold deposits of North Carolina: North Carolina Geological Survey Bulletin 3, p. 74-76.

Nitze, H.B.C., and Wilkens, H.A.J., 1897, Gold mining in North Carolina and adjacent south Appalachian regions: North Carolina Geological Survey Bulletin 10, p. 52-53

Noel, J.R., Sparious, D.J., and Dallmeyer, R.D., 1988, Paleomagnetism and ${ }^{40} \mathrm{Ar} /{ }^{39} \mathrm{Ar}$ ages from the Carolina slate belt, Albemarle, North Carolina: Implications for terrane amalgamation with North America: Geology, v. 16, p. 64-68

Offield, T.W., 1994, Lithotectonic map and field data—reconnaissance geology of the Carolina slate belt and adjacent rocks from southern Virginia to central South Carolina: U.S. Geological Survey Open-File Report 94-420, $58 \mathrm{p.}$

Offield, T.W., Kunk, M.J., and Koeppen, R.P., 1995, Style and age of deformation, Carolina slate belt, central North Carolina: Southeastern Geology v. 35 , p. $59-77$.

Pardee, J.T., and Park, C.F., Jr., 1948, Gold deposits of the Southern Piedmont: U.S. Geological Survey Professional Paper 213, 156 p.

Parduhn, N.L., Watterson, J.R., and Silberman, M.L., 1985, Recent studies of the distribution of Bacillus Cereus near subsurface gold deposits [abs.] in Kraft, K., ed., USGS Research on Mineral Resources, 1985, Program and Abstracts: U.S. Geological Survey Circular 949, p. 42.

Pogue, J.E., 1910, The Cid mining district of Davidson County, North Carolina: North Carolina Geological Survey Bulletin 22, 140 p.

Rogers, J.J.W., 1982, Criteria for recognizing environments of formation of volcanic suites: Application of these criteria to volcanic suites of the Carolina slate belt: Geological Society of America Special Paper 191, p. 99-109.

Scheetz, J.W., 1991, The geology and alteration of the Brewer gold mine, Jefferson, South Carolina: Unpublished M.S. thesis, Chapel Hill, NC, Chapel Hill University of North Carolina, $180 \mathrm{p}$.

Schmidt, R.G., 1985, High-alumina hydrothermal systems in volcanic rocks and their significance to prospecting in the Carolina slate belt: U.S. Geological Survey Bulletin 1562, 59 p.

Schroeder, K.E., 1987, Structure and stratigraphy related to gold mineralization at the Howie mine, south-central North Carolina: Unpublished M.S thesis, Athens, Ohio, Ohio University, $201 \mathrm{p}$.

Seal, R.R., II , Foley, N.K., Ayuso, R.A., and Offield, T.W., 1997, Genetic significance of regional sulfur isotope variations in gold deposits of the Carolina Slate Belt, South Carolina [abs.]: Geological Society of America Abstracts with Programs, v. 29, p. A-60.

Seal, R.R., II, Alpers, C.N., and Rye, R.O., 2000, Stable isotope systematics of sulfate minerals: Reviews in Mineralogy and Geochemistry, v. 40, p. $541-602$.

Seal, R.R., II, Ayuso, R.A., Foley, N.K., and Clark, S.H.B., 2001, Sulfur isotope geochemistry of hypogene mineralization at the Barite Hill gold deposit, S.C.: A window into and through regional metamorphism: Mineralium Deposita, v. 36, p. 137-148.

Seiders, V.M., 1981, Geologic map of the Asheboro, North Carolina, and adjacent areas: U.S. Geological Survey Miscellaneous Investigations Map I$1314,1: 250,000$.

Skillings Mining Review, 1993, Piedmont exploration results at N.C. property encouraging: Skillings Mining Review, March 6, 1993, p. 9.

Spence, W.H., Worthington, J.E., Jones, E.M., and Kiff, I.T., 1980, Origin of gold mineralization at the Haile mine, Lancaster County, South Carolina: Mining Engineering, v. 32, January 1980, p. 70-73.

Stein, H.J., Markey, B.J., Morgan, J.W., Zak, K., Zacharias, J., and Sundblad, K., 1996, Re-Os dating of Au deposits in shear zones using accessory molybdenite: Bohemian Massif, Carolina slate belt, and Fennoscandian shield examples: Geological Society of Amereica Abstracts with Programs, v. 28 , no. 7 , p. A- 474

Stromquist, A.A., and Henderson, J.R., 1985, Geologic and geophysical maps of south-central North Carolina: U.S. Geological Survey Miscellaneous Investigations Series, Map I-1400, scale 1:62,500. 
Stromquist, A.A., Choquette, P.W., and Sundelius, H.W., 1971, Geologic map of the Denton quadrangle, central North Carolina; U.S. Geological Survey Quadrangle Map GQ-872, scale 1:62,500.

Tomkinson, M.J., 1988, Gold mineralization in phyllonites at the Haile mine, South Carolina: ECONOMIC GEOLOGY, v. 83, p. 1392-1400.

Unger, H., 1982, Geology of the Union copper deposit, Gold Hill district, central North Carolina: Unpublished M.S. thesis, University of North Carolina at Chapel Hill, 86 p.

Watterson, J.R., Nishi, J.M., and Botinelly, T., 1984, Evidence that gold crystals can nucleate on bacterial spores, in Bartsch-Winkler, S. and Reed, K.M., eds., The United States Geological Survey in Alaska: Accomplishments during 1983: U.S. Geological Survey Circular 945, p. 1-5.

Worthington, J.E., and Kiff, I.T., 1970, A suggested volcanogenic origin for certain gold deposits in the slate belt of the North Carolina Piedmont: ECONOMIC GEOLOGY, v. 65, p. 529-537.
Worthington, J.E., Kiff, I.T., Jones, E.M., and Chapman, P.E., 1980, Applications of the hot springs or fumarolic model in prospecting for lode gold deposits: Mining Engineering, v. 32, p. 73-79.

Wortman, G.L., Samson, S.D., and Hibbard, J.P., 2000, Precise U-Pb zircon constraints on the earliest magmatic history of the Carolina terrane: Journal of Geology, v. 108, p. 321-338.

Yui, S., 1983, Textures of some Japanese Besshi-type ores and their implications for Kuroko deposits: ECONOMIC GEOLOGY MONOGRAPH 5, p. 231-240. Zierenberg, R.A., and Schiffman, P., 1990, Microbial control of silver mineralization at a sea-floor hydrothermal site on the northern Gorda Ridge: Nature, v. 348, p. 155-157. 